\title{
Zabúda Brno na Zbrojovku? Praktiky formovania urbánnej pamäti prostredníctvom individuálnej angažovanosti aktérov
}

\author{
Is Brno Forgetting Zbrojovka? Practices of Urban Memory \\ Formation Established through Individual Actors' Engagement
}

Ivana Rapošová, Apolónia Sejková, Csaba Szaló

\begin{abstract}
This article attempts to analyze controversies over a former armament factory called Zbrojovka Brno. The area, full of various and often contradictory symbolic meanings, constitutes a significant urban memory space. We claim that this brownfield forms a part of urban memory that extends beyond its built materiality, mainly through its symbolic presence in the practices of various social actors. The article encompasses two closely interlinked aspects of contemporary urban memory practices addressing the past lives in the city: those shaping what is remembered as well as those influencing what should be remembered in the future. The first consists of narratives circulating in the discourse of the actors who are engaged within this brownfield, and the second is represented by forms of justifications and critiques that are considered legitimate in disputes about the future of "Zbrojovka." The analytical framework used in this research draws on the theoretical contributions of Luc Boltanski and Laurent Thévenot, especially their pragmatic theory of justifiable orders of worth pluralism.
\end{abstract}

KEYWORDS Brownfield, Brno, pragmatic sociology, theory of justification, urban memory, Zbrojovka

\section{Úvod: Pamät' post-industriálnych miest}

Po mnohých zmenách, ktoré so sebou po nežnej revolúcií priniesla výmena režimov a ekonomická transformácia v Československu, bolo v roku 2007 definitívne rozhodnuté o zániku brnenskej Zbrojovky. ${ }^{1}$ Svojho času vel'mi významný podnik, ktorý spustil prevádzku ako štátna zbrojovka už v roku 1918, nesie názov podl'a výroby zbraní, ktoré boli na celom svete známe svojou kvalitou. ${ }^{2}$ Je miestom zrodu slávnych traktorov Zetor (Zet ako Zbrojovka) a vyrábali sa tu napríklad aj písacie stroje vzoru Remington. V čase najintenzívnejšej výroby, v 70. rokoch, vyžadoval podnik prácu tisícok zamestnancov. Po roku 1989 však dochádza

Sociální studia. Katedra sociologie FSS MU, 4/2013. S. 79-105. ISSN 1214-813X.

1 Text vznikl za finanční podpory Grantové Agentury ČR v rámci projektu „Kolektivní pamět’ a proměna městského prostoru“" (P404/12/2531).

2 Brnenská Zbrojovka (vedl’a Škody Plzeň a CKD Praha) patrila medzi podniky, ktoré po nacistickej okupácií Československa zaradili do tzv. Rišskeho zbrojárenského holdingu pod priamou nadvládou Göringa, vid' Franěk (1969). 
k postupnému obmedzovaniu výroby, až sa Zbrojovka dostáva do konkurzu. Zánik, teda potvrdenie definitívneho konca vlastnej strojárenskej výroby, vyhlásil nový majitel', finančná skupina J\&T, po dražbe, ktorá bola rekordná v českej histórii: areál Zbrojovky bol investorovi predaný za 707 miliónov Kč. ${ }^{3}$

Po ukončení výroby v Zbrojovke vystala otázka, ako naložit's jej rozl'ahlým industriálnym areálom. Dvadsat'hektárový pozemok v centre Brna s budovami z prvej polovice dvadsiateho storočia, ale aj neskoršími dostavbami, je momentálne $\mathrm{v}$ správe firmy, ktorá prenajíma čast' budov nachádzajúcich sa ešte $\mathrm{v}$ použitel'nom stave pre účely drobného podnikania či umeleckých aktivít. Súčasný stav je však len dočasným riešením, nakol'ko majitel' už ohlásil svoj zámer: vybudovat' na ploche obchodno-bytové centrum, na ktoré už bol vytvorený architektonický zámer. Búracie práce sú však zatial’ pod vplyvom ekonomickej krízy, nejasnej situácie s novým územným plánom a pripomienkovaním rozhodnutia o búraní areálu odložené na dobu neurčitú.

Domnievame sa, že na celú situáciu ohl'adom transformácie tohto kedysi slávneho a dôležitého podniku je možné nazerat' ako na určitú relatívne významnú príležitost' pre mesto Brno a jeho občanov, ako sa vyrovnat' so svojim industriálnym dedičstvom a presadit' špecifickú víziu budúcnosti areálu Zbrojovky konkrétne a industriálnych častí Brna všeobecne. Príležitost'ou v tomto kontexte rozumieme možnost' rôznorodých aktérov spolupodiel'at' sa svojou argumentáciou a sociálnym konaním na premene Zbrojovky a prezentovat' tak svoje záujmy (v materiálnej i nemateriálnej forme).

Navyše, nakol'ko továreň Zbrojovka Brno bola jedným z najdôležitejších symbolov českej industriálnej epochy, vnímame tento konkrétny prípad ako významný a vypovedajúci aj $\mathrm{z}$ hl'adiska širších tendencií prístupu $\mathrm{k}$ industriálnemu dedičstvu v Českej republike.

Prudký rozvoj mnohých miest v priebehu 19. a 20. storočia šiel ruka v ruke s industrializáciou, ktorá podnietila vznik mnohých tovární. Tieto podniky však s príchodom politických, ekonomických a sociálnych zmien koncom 20. storočia a pod vplyvom postupnej globalizácie ukončili, presunuli, či radikálne obmedzili svoju činnost'. Mestá tak vstúpili do novej fázy svojho cyklu, ktorú dnes nazývame post-industriálom. V tejto fáze sa mení zameranie ekonomickej činnosti, intenzívnu industriálnu výrobu nahrádza tzv. „knowledge economy“ a odvetvia l'ahkého priemyslu (Martin a Rowthorn 1986; Lněnička 2012). Fyzickou pripomienkou celej tejto zmeny často ostávajú nevyužívané či len čiastočne využívané bývalé industriálne komplexy, pre ktoré sa v urbánnom plánovaní a mestskej správe všeobecne začalo používat' slovo brownfield. ${ }^{4}$

Komplex Zbrojovky je prípadom, akých môžeme v našej časti Európy v súčasnosti nájst' vel'ké množstvo: ide o areál, ktorý bol v svojej dobe dôležitým industriálnym centrom, ale dnes leží viac menej ladom a pomaly chátra. Navyše, tento areál bol postavený na okraji vtedajšieho

\footnotetext{
História továrne je spracovaná na webových stránkach Zbrojovky Brno (Zbrojovka 2013).

Národná stratégia regenerácie brownfields v Českej republike definuje brownfield ako „,nehnutel'nost' (pozemok, objekt, areál), ktorá je nedostatočne využívaná, zanedbaná a môže byt' i kontaminovaná“, a ktorá „vzniká ako pozostatok priemyselnej, pol’nohospodárskej, rezidenčnej, vojenskej, či inej aktivity“. Určujúcim znakom brownfieldu je z pohl'adu tejto koncepcie fakt, že bez procesu regenerácie ho nie je možné plnohodnotne využívat'.
} 
mesta, ked’že sa však mesto rozrastalo, nachádza sa dnes v širšom centre, čo z neho robí zaujímavú investičnú príležitost', ale aj problém, o ktorý sa zaujímajú mestskí plánovači.

Okrem investičných a urbanistických zámerov, v ktorých areál figuruje, je Zbrojovka aj objektom, ktorý pripomína príbeh industrializácie mesta, zmeny štruktúry obyvatel'stva, vojnovú výrobu, budovatel'ské obdobie socializmu či nekalé praktiky z dôb „divokého kapitalizmu“. Materiálne objekty v mestách majú potenciál uchovávat’ práve takéto významy: teoretik architektúry Aldo Rossi mestu pripisuje schopnost' „pamätat' si“ prostredníctvom budov, ktoré v ňom stoja. Ak je demolačnými mestskými prestavbami narušená možnost' obyvatel'ov sledovat' historické materiálne premeny mesta, v ktorom žijú, je pre nich t’ažké zvýznamnit' toto mesto, pretože materializovaná pamät' už neslúži ako sprievodca týmto procesom (Crinson 2005). Miesta pamäti, lieux de mémoire, slúžia spoločnosti, ktorá už nedisponuje organickou pamät'ou komunít, ale stále potrebuje objekty alebo miesta, ktoré jej budú pripomínat' kontinuitu a ukotvovat' tak identitu jedinca v sociálnom svete (Nora 1989; Guibernau 2007: 10). Ak zdiel'ané obsahy pamäti už nešíria d’alej aktéri spomínaných dejov a ich súčasníci, táto komunikatívna, živá pamät’ sa bud' stratí, prirodzene „,vymrie“, alebo sa stáva kultúrnou pamät'ou, pamät'ou externalizovanou a uloženou v symbolických obsahoch tak, že je možný jej prenos medzi situáciami i generáciami (Assman 2011:17). Symboly zohrávajúce v tomto procese kl'účovú rolu môžu mat’ formu materiálnu (múzeá, pomníky, ale napríklad aj samotné budovy), alebo nemateriálnu (sviatky, rituály a oslavy).

Práve spomienky na industriálnu éru môžu byt' v rámci procesov cieleného vytvárania symbolov (tzv. memory politics) opomínané. Predstavitelia mestských politík nemusia mat' záujem na pripomínaní industriálnej minulosti mesta, u ktorého chcú vytvorit’ obraz čistého, konzumujúceho moderného sídla, ktoré za svojou minulost'ou urobilo hrubú čiaru, a do tohto obrazu industriálne komplexy s ,esteticky nulovou hodnotou“ náležat' nemusia (Fainstein 2005). V opozícií k tomuto trendu však existuje aj mnoho zástancov industriálnej architektúry, jej špecifického genia loci, či obhajcov nutnosti uchovania fyzických pripomienok ako symbolických miest pamäti zmien, ktoré postupne nastávali. ${ }^{5}$

Zbrojovka má potenciál byt' práve takýmto symbolom, ak by sa na potrebnosti jej ustanovenia ako miesta spomínania zhodli aktéri, ktorí majú na vytvorenie takéhoto miesta potrebný dosah. Podl’a nášho názoru sa Zbrojovka nachádza v súčasnosti v momente, od ktorého závisí rozsah a spôsob kultivovania tejto časti pamäti mesta Brna.

\section{Príbehy o Zbrojovke}

Praktiky, ktoré formujú skúsenosti a priestory urbánnej pamäti, ponúkajú dobré príklady toho, ako je sociálne konanie vždy dynamickou konfrontáciou dvoch typov vedenia prepájajúceho nás so svetom: a) realizmu ako mapy zobrazujúcej to, ako to vo svete chodí;

5 Príkladom je Charta industriálneho dedičstva, ktorá hovorí, že „,materiálne dôkazy týchto zásadných zmien majú univerzálnu hodnotu a musíme si uvedomit' dôležitost' štúdia a uchovania týchto dôkazov“" nakol'ko ,industriálne dedičstvo má spoločenskú hodnotu ako súčast' uchovania stopy po životoch obyčajných mužov a žien, a ako také poskytuje dôležitý pocit identity“. Vid' The International Committee (2003). 
a b) moralizmu ako mapy, ktorá nás môže viest' na našej ceste pri hl'adaní dobrého života (Thévenot 2001: 5-6). Materiálnost' mestských priestorov (urban landscapes), podobne ako v týchto priestoroch odohrávajúce sa praktiky spomínania na minulé životy a udalosti späté s týmito priestormi, sú nositel'mi stôp dejinne daných podôb hl'adania dobra a dôverného vzt'ahu k realite. Naša snaha porozumiet' procesu formovania urbánnej pamäti vzt'ahujúcej sa k brnenskej Zbrojovke nebola zameraná na praktiky spomínania utlačovaných a/alebo autentických pamätníkov, ale na diskurz aktérov, ktorí sa na formovaní tohto priestoru urbánnej pamäti podiel'ajú. ${ }^{6}$

Dynamika konfrontácie dôverného vzt’ahu k realite s hl'adaním dobra pri formovaní priestorov urbánnej pamäti je podl'a nášho názoru prítomná ako v praktikách bývalých robotníkov, inžinierov, miestnych aktivistov a umelcov, tak v konaní plánovačov, architektov, pamiatkarov a developerov.

Na základe pragmatickej sociológie (Boltanski a Thévenot 2006; Boltanski 2011: 103-110, 2007), ktorá kladie dôraz na to, že l’udské konanie má vždy podobu praktického zapojenia aktérov, tj. odohráva sa v súbežnom vzt’ahu aktérov k materiálnym a morálnym štruktúram ich sveta, môžeme rozlíšit' štyri formy angažovanosti (engagement) v oblasti formovania urbánnej pamäti brnenskej Zbrojovky. ${ }^{7}$ Tieto analytické typy angažovanosti nám taktiež umožnili identifikáciu sociálnych aktérov, ktorí sa podiel'ajú na formovaní urbánnej pamäti, a tým pádom sa mohli stat' komunikačnými partnermi v našom výskume: ${ }^{8}$ a) angažovanost' prostredníctvom inštitucionalizovaného konania legitimizovaného verejným diskurzom o zdiel'anom dobre; príkladom môžu byt' politici, úradníci, plánovači, aktivisti; b) angažovanost' prostredníctvom plánovaného autonómneho konania nasledujúceho individuálny biografický projekt, ktorý je legitimizovaný prísl'ubom sebarealizácie; príkladom môžu byt' architekti, developeri, novinári, výskumníci, ale aj politici, úradníci; c) angažovanost' prostredníctvom habitualizovaného konania vo familiárnom prostredí žitého sveta, ktorý je legitimizovaný zvykom a každodennými aktivitami; príkladom môžu byt' robotníci, dozorcovia

6 Je to v súlade s prístupom Marka Crinsona (2005), ktorý v tejto rovine vychádza z Kleinovej (2000) kritiky tzv. priemyslu spomínania. Klein tvrdí, že súčasný akademický diskurz prispieva k terapeutickému, moralizujúcemu a spiritualizujúcemu ponímaniu kultúrnej pamäti.

7 Na tomto mieste si musíme pripomenút’ štúdiu (Durnová 2013), ktorá na základe empirického výskumu spracováva kontroverziu týkajúcu sa presunu hlavnej stanice v Brne. Štúdia prináša relevantné poznatky ako o dynamike formovania urbánnej pamäti, tak o zapojení aktérov v kontroverzii. Výsledky výskumu Durnovej a výsledky nášho výskumu sú však t’ažko porovnatel'né (ak vôbec), ked’že vychádzajú z nekompatibilných teoretických rámcov a metodologických prístupov diskurzívnej lingvistiky a pragmatickej sociológie. Pre empirické využitie pragmatickej sociológie v stredoeurópskom kontexte vid' Klocoková a Findor (2008) a Klocoková (2010).

8 Individuálni sociálni aktéri môžu byt' nositel'mi viacerých podôb angažovanosti súčasne. Jadro výskumu tvorí 11 rozhovorov, ktoré pokrývajú hore zmienené typy angažovanosti. V súlade $\mathrm{s}$ našim analytickým rámcom nepristupujeme $\mathrm{k}$ aktérom výlučne ako ku kategóriám na základe napríklad ich pracovného zaradenia, ale snažíme sa postihnút' práve aj spôsob, akým sa k objektu Zbrojovky vzt’ahujú. Preto uvádzame v texte nielen krátku prezývku komunikačného partnera (napríklad Umelec, Správca Zbrojovák, Organizátor...), ale aj spôsob/y, akým sú vo veci Zbrojovky zapojení. 
či miestni obyvatelia; d) angažovanost' prostredníctvom kreatívneho konania, ktoré v kontraste s habitualizovanými formami konania sleduje inováciu foriem, prekračuje pravidlá a je legitimizované predpokladom nepredvídatel'nosti budúcnosti a imperatívu objavovania príkladom môžu byt' umelci, architekti, výskumníci, developeri.

Pojem angažovanosti v špecifickej oblasti sociálneho sveta zohl'adňuje to, že každá podoba vzt'ahovania sa $\mathrm{k}$ svetu je vždy prepletená so špecifickým režimom dobra a špecifíckou formou dôvery v realitu. ${ }^{9} \mathrm{Aj}$ z hl'adiska formovania urbánnej pamäti je kl’účové, že zapojenie sa konajúcich do sveta sa uskutočňuje prostredníctvom dôverného vzt'ahu k špecifickému náhl'adu na realitu, ktorú so svojím kategorizačným a evaluačným poriadkom reprezentuje špecifický režim dobra. Boltanski a Thévenot (1999, 2006) rozlišujú šest’ ideálne typických svetov a k nim sa viažucich režimov dobra: inšpiračný, domáci, občiansky, názorový, trhový a priemyslový (vid' tabul'ka 1). Analytickým ciel'om nášho výskumu bolo práve odhalenie špecifických režimov dobra pôsobiacich v pozadí praktík formovania urbánnej pamäti v prípade brnenskej Zbrojovky. Sústredili sme sa preto na proces ozmyselňovania budúcnosti areálu Zbrojovky, špecificky na argumentačné štruktúry ospravedlňovania, ktoré si a) nárokujú autoritu uzavriet' spor, skúmanie, vyšetrovanie a ukončit' pochybnosti, alebo si naopak b) nárokujú autoritu kritickej destabilizácie dôvery prostredníctvom otvorenia sporov a preskúmaním pochybností. Tieto štruktúry ospravedlňovania, ako v afirmatívnej tak v kritickej forme, obsahujú vždy ako morálno-evaluačné, tak aj realisticko-kognitívne podoby argumentov. Práve túto prepojenost' moralizácie a realizmu sme sa pokúsili zachytit' zobrazením štruktúry ospravedlňovania formou príbehov. Príbehy o Zbrojovke nemajú jednotného

Tabul'ka 1: Ideálne typické svety a k nim sa viažuce režimy dobra

\begin{tabular}{|l|l|l|l|l|l|l|}
\hline Svet & Inšpiračný & Domáci & Občiansky & Názorový & Trhový & Priemyselný \\
\hline $\begin{array}{l}\text { Režim } \\
\text { dobra } \\
\text { (order of } \\
\text { worth) }\end{array}$ & $\begin{array}{l}\text { Nadanie, } \\
\text { nekonformnost', } \\
\text { kreativita }\end{array}$ & $\begin{array}{l}\text { Úcta, } \\
\text { reputácia }\end{array}$ & $\begin{array}{l}\text { Kolektívny } \\
\text { záujem }\end{array}$ & $\begin{array}{l}\text { Sláva, dobrá } \\
\text { povest }\end{array}$ & Cena & $\begin{array}{l}\text { Produktivita, } \\
\text { efektivita }\end{array}$ \\
\hline $\begin{array}{l}\text { Formát } \\
\text { relevantnej } \\
\text { informácie }\end{array}$ & Emócie & $\begin{array}{l}\text { Ústne } \\
\text { podanie, } \\
\text { príklad, } \\
\text { anekdota }\end{array}$ & $\begin{array}{l}\text { Formalita, } \\
\text { oficiálnost }\end{array}$ & Význam & Mena & $\begin{array}{l}\text { Meratelnost: } \\
\text { kritérium, } \\
\text { śtatistika }\end{array}$ \\
\hline $\begin{array}{l}\text { Základný } \\
\text { vzfah }\end{array}$ & Vášeň & Dôvera & Solidarita & Rozpoznanie & Výmena & $\begin{array}{l}\text { Funkčné } \\
\text { prepojenie }\end{array}$ \\
\hline $\begin{array}{l}\text { L'udská } \\
\text { kvalita }\end{array}$ & $\begin{array}{l}\text { Kreativita, } \\
\text { vynaliezavost' }\end{array}$ & Autorita & Rovnost' & Osobitosf' & $\begin{array}{l}\text { Žiadostivosf', } \\
\text { zaobstarávanie } \\
\text { moci }\end{array}$ & $\begin{array}{l}\text { Profesionálna } \\
\text { kompetencia, } \\
\text { expertíza }\end{array}$ \\
\hline
\end{tabular}

Zdroj: Boltanski a Thévenot (1999, 2006)

9 Boltanski a Thévenot používajú v originálnom texte francúzske slovo „les cités“, ktorého asi najvýstižnejší preklad do slovenčiny by bol „politická obec“. Reflektujúc anglický preklad a terminológiu využívajúcu slovo „,world“ však budeme pre lepšiu prehl'adnost' a zrozumitel'nost' v texte pracovat' so slovom „svet“. Termíny „svet“ alebo ,ideálne- typický svet“ tak v texte slúžia na označenie sociálnej reality vsadenej do určitej formy hodnotenia a podriadenej špecifickému režimu dobra. 
rozprávača, ako kolektívne pamätové naratívy sú skladačkou výpovedí a interpretácií rozličných aktérov. Títo so Zbrojovkou prepojení aktéri sa v argumentácií môžu odkazovat' na odlišné režimy dobra a nie sú tak limitovaní účastou v jedinom príbehu, práve naopak, v závislosti od foriem angažovanosti sa ich argumentácia môže podiel'at' na skladaní a udržiavaní pri živote viacerých pamätových naratívov, z ktorých niektoré majú šancu stat' sa dominantnejšími než ostatné.

\section{Príbeh prvý: Zbrojovka ako svetový podnik a symbol pokroku}

Prvotný príbeh o Zbrojovke sa viaže k samotnému vzniku a industriálnej sláve podniku a je dôležitý predovšetkým z hl'adiska navodenia všeobecného kontextu, čím Zbrojovka kedysi bola a prečo by vôbec mohla byt' považovaná za dôležitú. Slovami dobového historika je to príbeh o tom, ako spočiatku z podceňovanej továrne lokálneho významu vyrástol v priebehu relatívne krátkeho obdobia medzi dvoma svetovými vojnami „mohutný a dobre organizovaný zbrojársky koncern, s dokonalým strojovým parkom, priebojným výskumom, s mnohými tisícmi zamestnancov $\mathrm{v}$ rôznych častiach republiky, s mnohostrannými obchodnými záujmami, doslova obopínajúci svojou obchodnou sietou celý vtedajší kapitalistický svet“ (Franěk 1969: 5). ${ }^{10}$ Taktiež je to príbeh o tom, ako sa z miesta výroby zbraní vyvážaných na nemecký front stalo postupne miesto technologickej excelencie, kde sa podl'a nášho komunikačného partnera „kvalita a presnost' vyrobených súčiastok dala porovnávat' s výrobou v Švajčiarsku“.."11

Československá štátna Zbrojovka bola založená v roku 1918 a napriek tomu, že do určitej miery nadviazala na tradíciu rakúsko-uhorských delostreleckých dielní, bola od samotného vzniku považovaná za rýdzo český podnik (Franěk 1969: 13). Je možné sa domnievat', že v kontexte vtedajšej socio-politickej situácie mal práve z tohto dôvodu vznik továrne pre Československo vel'ký význam. Zbrojovka dodnes ostáva pre mnohých symbolom prvej republiky a technologických inovácií, avšak v rozpore s obrazom Zbrojovky na vrchole slávy

10 Otakar Franěk píše o Zbrojovke na prelome 60. a 70. rokov, sám teda popisuje okolnosti založenia továrne s odstupom niekol'kých dekád a s optikou odlišnej doby. Nakol'ko však táto stat' nemá ambíciu stat' sa historickou štúdiou a Franěkove publikácie predstavujú jediný nám dostupný historický zdroj, rozhodli sme sa s ním pri načrtnutí kontextu aj napriek možnému skresleniu pracovat'. Existencia týchto publikácii, vydaných pri príležitosti 50 . výročia od založenia fabriky, je tak sama o sebe významnou výpoved’ou o špecifickom postavení Zbrojovky v porovnaní s ostatnými továrňami v okolí Brna.

11 Správca Zbrojovák pracoval v Zbrojovke ešte za minulého režimu a ako pracovník firmy spravujúcej areál tam pôsobí dodnes. Dnes sa primárne vzt’ahuje k Zbrojovke ako k miestu, ktoré mu dáva obživu a je súčast'ou jeho každodennosti. V situácii rozhovoru pre vysvetl'ovanie príbehu Zbrojovky sa správca vzt’ahoval k minulosti väčšinou zdôrazňovaním hodnôt priemyselného a názorového sveta, v rámci pohl'adu spät' nostalgicky popisoval vzt'ahy dôvery a solidarity v kolektíve pracovníkov, teda hodnotil jej význam z pohl’adu názorového a domáceho sveta. 
počas socializmu prezentovaným Franěkom (1973) je Zbrojovka súčasne aj symbolom „sovietskeho pokorenia". ${ }^{12}$

$\mathrm{V}$ prvopočiatkoch fungovania sa výroba $\mathrm{v}$ Zbrojovke zameriavala predovšetkým na opravu zbraní použitých v prvej svetovej vojne. „Dielne boli prepchaté rôznymi poškodenými súčast’ami zo všetkých možných frontov. Tieto trosky výzbroje tu čakali trpezlivo na opravu, aby sa nad'alej mohli podiel'at' na zabíjaní vo vel'kom“"(Franěk 1969: 11). ${ }^{13}$

Postupne sa podnik začal viac profilovat', v Zbrojovke bola ako vôbec v prvej zbrojárenskej továrni zavedená sériová výroba súčiastok, ktoré sa následne stali vol’ne zamenitel'nými. V 20. rokoch sa Zbrojovka zaradila medzi najväčších výrobcov pušiek na svete a $\mathrm{v}$ rokoch tridsiatych začala kontinuálne skupovávat' akcie $\mathrm{v}$ zbrojárenských podnikoch v okolitých štátoch a postupne rozširovat' výrobu o automobily, písacie stroje Remington, traktory Zetor, ale aj kancelársku a výpočtovú techniku. ${ }^{14} \mathrm{Za}$ hranicami Zbrojovku preslávil aj l'ahký gul'omet vz. 26, ktorý skonštruoval a uviedol do masovej výroby Václav Holek pracujúci v brnenskej Zbrojovke. Licenciu zakúpila Vel'ká Británia, kde sa gul’omet modifikoval a vyrábal pod značkou BREN. ${ }^{15}$ Povedomie o Zbrojovke je vd’aka zbraniam dodnes z časti prítomné aj za hranicami Čiech a môže zohrávat' rolu pri identifikácií mesta Brna cudzincami a byt' tak zdrojom určitej hrdosti pre jeho obyvatel'ov. ${ }^{16}$

My sme boli celkom elitný výrobca zbraní a až do roku 89 sa to dalo porovnávat' s výrobou v Nemecku, alebo tak, ale tie naše zbrane boli precíznejšie v tom, že boli vyrábané tak, aby sa to nedalo poskladat' nejakou nekvalifikovanou silou. Tam sa vyrobili tie kusy a pri montáži sa dopasovávali, aby tam boli tie medzery medzi tým minimálne, a tým sa vlastne zväčšovala kvalita výrobku. Nebolo možné, že ste tu mali bedňu so súčiastkami a tu tiež a skladali ste to ako lego a vypadla z toho zbraň, to nie. To sa tu robilo kus od kusu. (Správca Zbrojovák)

Zbrojovka sa tak ako „svetový podnik svojho oboru“ stala jedným z hlavných symbolov českého priemyslu, zdrojom pýchy českej (a špecificky moravskej) industrializácie a dôkazom, že česká výroba je schopná obstát’ v medzinárodnej konkurencii (Franěk 1969: 5).

12 Komunikačný partner Architekt asocioval Zbrojovku s prvou republikou, slávnym gul'ometom BREN, ako aj úpadkom technologického rozvoja počas sovietskych zásahov do výroby a vzniku RVHP. Toto sa javí byt' vrozpore s Franěkom prezentovaným pohl'adom o rozkvete továrne, ktorý bol počas obdobia pod vplyvom ZSSR výrazný.

13 Ako však ukázali naše výskumné rozhovory, komunikační partneri vojnovú konotáciu a násilie ani podiel Zbrojovky na bombardovaní Brna počas druhej svetovej vojny nijakým spôsobom neakcentovali.

14 História továrne je spracovaná na webových stránkach Zbrojovky Brno (Zbrojovka 2013).

15 Viac o vývoji gul'ometu BREN a jeho väzbe na Zbrojovku píše Pavel Kurka na webových stránkach www.military.cz. Tento konkrétny gul'omet je spomedzi iných zbraní a technologických vynálezov Zbrojovky dôležitý práve preto, lebo jeho symbolický význam bol natol'ko silný, že prenikol až do architektonického plánu Novej Zbrojovky, kde má byt' sprítomnený ako súčast' názvu novej kaviarne „Cafe Bren“, vid’ webové stránky Pelčák a Partner architekti (Pelčák a Partner 2009).

16 Komunikačný partner Architekt popísal osobný zážitok, ked’ bol príjemne prekvapený, že l’udia v zahraničí vedia zaradit' Brno ako české mesto, pretože ho poznajú ako výrobcu dobrých pušiek. 
Étos o výnimočnosti Zbrojovky nebol prezentovaný len elitami, ale bol do určitej miery zdiel'aný aj samotnými zamestnancami a ostatnými obyvatel'mi mesta Brna. ${ }^{17}$

...A tí Zbrojováci, to bola taká šl’achta mezi robotníkmi, pretože oni boli vtedy úžasne pri práci, povedal by som vtedy vo všeobecnosti na tie pomery, pretože boli schopní si postavit' vel'mi pekné domčeky v tých Žideniciach. To bola taká skromná vilová štvrt', alebo povedzme také radové domy a dvojdomy, [...] bol to vel'mi dobrý prvorepublikový štandard. Takže to ma samozrejme zaujímalo, mal som k tomu vzt'ah, bola to súčast' akejsi hrdosti, nielen mesta. Volalo sa to Zbrojovka Brno... (Aktivista) ${ }^{18}$

Práca v Zbrojovke bola zamestnancami vnímaná pozitívne ako „tak trošku iná“ ako v ostatných podnikoch, čo bolo dané predovšetkým pocitom špecifickej kolektívnej identity a odbornost'ou zamestnancov.

Tá zložka tej radosti z toho, že sa podiel'am na tom výrobku, že som do toho dal tiež niečo svojho, že som sa zapojil do toho kolektívu, to nebolo len ako konštruktéri. To bolo v rátane tej výroby a kontroly, to robilo dokopy tú partiu, kde sa vyrábali tie krásne pekné veci. [...] Boli tu majstri s vel'kým M. (Správca Zbrojovák)

Zbrojovka tak bola od svojho vzniku viac ako osemdesiat rokov silným ikonickým symbolom Žideníc a mesta Brna, pričom bol ale jej konkrétny význam vždy podmienený aktuálnou politickou situáciou a prevládajúcou štátnou ideológiou. ${ }^{19}$ Kým počas obdobia prvej československej republiky bola predovšetkým symbolom českej štátnosti a národného obrodenia, v období protektorátu zohrávala významnú úlohu pri podpore nacistického Nemecka a zásobovaní Wehrmachtu, ale aj komunistického odboja, zbran̆ami a v dobe socializmu zase v súlade $\mathrm{s}$ aktuálnymi spoločenskými hodnotami reprezentovala akýsi ideál socialistického podniku a robotníckej triedy.

\section{Príbeh druhý: Futbalová Zbrojovka}

Ked' sa dnes v Brne povie Zbrojovka, nemusí sa jednat' len o samotnú továreň. V roku 1913 bol v Žideniciach založený futbalový klub SK Židenice, ktorý sa stal druhým najstarším

17 Na tomto mieste je samozrejme vhodné zamysliet'sa, nakol'ko bola deklarovaná hrdost' zamestnancov na podnik výsledkom ich vnútorného presvedčenia o dobrých pracovných podmienkach a kvalite výroby, a nakol'ko akýmsi zvnútornením celkovej propagandy okolo Zbrojovky. Vzhl'adom na charakter vtedajšej doby je možné predpokladat', že postoje zamestnancov boli budovatel'skou ideológiou aspoň do určitej miery ovplyvnené.

18 Aktivista pokúšajúci sa o zachovanie čím viac materiálnych stôp existencie fabriky v Zbrojovke nikdy nepracoval, angažuje sa prostredníctvom inštitucionálneho konania (odvolania a pripomienky oficiálnych dokumentov, vyjednávanie s politikmi a plánovačmi), ktoré je legitimizované verejným diskurzom o zdiel'anom dobre. Toto zdiel'ané dobro je posudzované z pozície verejného záujmu, celú jeho argumentáciu sprevádzajú režimy občianskeho sveta, v tomto prípade aj názorového či domáceho.

19 Židenice boli až do roku 1990 samostatnou obcou, k Brnu boli ako mestská čast' pričlenené až koncom 20. storočia. Vid’ webové stránky mestskej časti Židenice. 
futbalovým klubom v okolí Brna a taktiež jedným z najpopulárnejších. Napriek tomu, že spojenie medzi Zbrojovkou a židenickým futbalom nebolo prítomné od samotného vzniku klubu, relatívne rýchlo sa ustanovilo. Zbrojovka začala SK Židenice materiálne i nemateriálne podporovat', došlo $\mathrm{k}$ previazaniu mnohých pracovných postov a funkcií v továrni a športovom klube a futbalisti našli v Zbrojovke trvalé zamestnanie, ktoré slúžilo čiastočne aj ako krytie ich hráčskeho vyt’aženia (Čapka a Zabloudil 2013). ${ }^{20}$ Ked' bol klub SK Židenice v roku 1947 premenovaný na SK Zbrojovka Židenice, a neskôr na Sokol Zbrojovka Židenice, jednalo sa o akési „logické zlúčenie klubu a továrne“ (Čapka a Zabloudil 2013: 91).

Klub v nasledujúcich dekádach niekol'kokrát zmenil meno, ale po väčšinu svojej existencie si ponechával $\mathrm{v}$ názve slovo Zbrojovka, čím vyjadroval jasnú príslušnost' $\mathrm{k}$ svojmu hlavnému podporovatel'ovi. ${ }^{21}$ Zbrojovka tak vstúpila do širšieho povedomia Brňanov nielen vo výrobnej sfére, ale aj v oblasti športu. ${ }^{22}$ Továreň ako aj športové oddiely fungujúce pod Zbrojovkou boli podl'a vyjadrenia obyvatel'a Brna a bývalého funkcionára futbalového klubu vnímané ako prominentná záležitost':

...ked' bol niekto v Zbrojovke, tak to malo zvuk. Malo to zvuk na šport, pretože to boli špičkoví športovci v Zbrojovke, tí čo na to nemali, tak išli do iných nižších klubov, napríklad do Slávie. Tiež mali ihrisko, robili atletiku a futbal, ale nedosahovali tie výsledky. Tá Zbrojovka mala zvuk a hlavne im mala tá fabrika čo dat'. Išli do zahraničia, čo sa vtedy vel'mi nerobilo, tá fabrika im dala autobus a išli. (Futbalový funkcionár na dôchodku) ${ }^{23}$

Z hl'adiska utvárania kolektívnej pamäti o Zbrojovke je vel'mi zaujímavé venovat' pozornost' okolnostiam vývoja zmien pomenovania futbalového klubu. Privatizácia a ukončenie výroby $\mathrm{v}$ továrni mali totiž za následok aj osamostatnenie klubu, ktorý bol nútený hl'adat' nových sponzorov a prijat' ich meno do svojho názvu. V roku 2010 sa však klub po 18 ročnej prestávke k odkazu Zbrojovky opät' prihlásil a zmenil svoje meno na FC Zbrojovka Brno. ${ }^{24}$

20 Autori narážajú na fakt, že v dobe vzniku futbalového klubu neexistoval v Československu štatút profesionálnych športovcov a tí, aj ked' sa futbalu venovali aj počas pracovnej doby, museli byt' niekde formálne vedení ako zamestnanci.

21 Medzi rokmi 1954-1968 sa futbalový klub volal SPARTAK BRNO ZJŠ, pričom však ZJŠ bolo odkazom na Závody Jana Švermy, vtedajší názov zbrojárenskej továrne (Čapka a Zabloudil 2013). Analógia so Zbrojovkou tak bola v tejto dobe udržiavaná aj napriek odlišnému názvu. Presnú históriu zmeny mien je možné nájst' na webových stránkach FC Zbrojovky.

22 Za zmienku stojí, že v dobe socializmu fungovali v rámci telovýchovnej jednoty Zbrojovky aj mnohé iné športové oddiely (volejbalisti, hokejisti, atléti, turisti...) a boli tak nositel'om jej mena. Nakol'ko však tieto oddiely spolu so zánikom telovýchovných jednôt svoju činnost' ukončili, alebo zmenili meno, nie je pre náš výskum relevantné.

23 Futbalový funkcionár na dôchodku sa k Zbrojovke, ktorá je preňho klubom, vzt’ahuje ako k habitualizovanej, žitej skúsenosti, a považuje za dôležité, aby bola zachovaná symbolická zvyklost' spájania klubu so Zbrojovkou a s Brnom.

24 Medzi rokmi 1992 a 2010 sa futbalový klub volal FC Boby Brno, FC Boby Brno Unistav, FC Boby-sport Brno, FC Stavo Artikel Brno a 1. FC Brno. Vid' webové stránky FC Zbrojovka Brno (FC Zbrojovka). 
Aký bol teda dôvod opätovného symbolického stotožnenia sa s dnes už neexistujúcou fabrikou? Podl'a slov bývalého zamestnanca sa futbalový klub snažil reagovat' predovšetkým na požiadavky verejnosti, ktorá si to vyžiadala, ,pretože to malo tradíciu, pretože najdlhšie to bola Zbrojovka“، Zbrojovka je dnes teda vo futbale metaforou Brna: „Ked' ten dav l'udí kričí Zbrojovka, to znie krásne. Stavoartikl nikto nepovzbudzoval. Bud’ Brno, alebo Zbrojovka,“ ale zároveň je meno samotné metonýmiou k industriálnemu komplexu na druhom konci mesta a odkazuje k príbehu Zbrojovky, a tým pádom k histórii brnenskej industriálnej výroby všeobecne.

Význam tohto kroku na poli kultivácie pamäti je podčiarknutý aj faktom, že kým v minulosti plynuli klubu z prijatia mena sponzora určité finančné prostriedky, v súčasnosti musí FC Zbrojovka Brno na základe zmluvy o nástupníctve platit’ Zbrojovke Uherské Hradiště za používanie tohto názvu poplatok. ${ }^{25} \mathrm{~V}$ prípade návratu klubu k menu FC Zbrojovka tak bola hlavným argumentom dôležitost' referencie ku sláve a dobrej povesti, režimy dobra typické pre perspektívu názorového sveta, a to aj napriek nutnosti finančnej investície.

Podl'a komunikačného partnera z umeleckej komunity je však prepojenie pamäti na továreň a futbalu až príliš silné, pretože mnoho l'udí v Brne asociuje meno Zbrojovka už len s futbalom:

Ono je to také nevedomie, l'udia to už nejako vytesnili z hlavy, Zbrojovka už je pre nich len hokej alebo futbal, nie to meno. Pre tie staršie ročníky to je meno pre nejaké výrobky, ale myslím si, že je s tým spojených vel’a vecí v histórií. Zbrojovka, to predsa nie je až tak negatívne, ale malo to aj vel’a zaujímavých vecí. (Sochár) ${ }^{26}$

Komunikačný partner tak vyzdvihuje fakt, že by bola škoda, ak by bola pamät' na významnú továreň obmedzená len na asociáciu s futbalovým klubom, a iné príbehy viažuce sa aj k miestu, areálu Zbrojovky, neboli v brnenskom pamätovom diskurze prítomné.

\section{Príbeh tretí: Krach slávnej továrne a Zbrojovka po roku 1989}

Dôležitým príbehom viažucim sa k Zbrojovke je aj vysvetl'ovanie spôsobu, akým táto dôležitá fabrika prestala po zmene režimu postupne fungovat'. Príbeh, ktorý bolo možné extrahovat' z rozprávania l'udí so vzt’ahom k Zbrojovke, sa odvíja okolo tém nádeje po roku 1989,

25 O návrat k menu Zbrojovky sa zaslúžil Václav Bartoněk, ktorého médiá označujú aj „brnenským patriotom“", ked” odkúpil licenciu na meno Zbrojovka na desat’ rokov. Od mája 2013 sa zároveň stal aj novým vlastníkom klubu. Vid’ Robin Krutil v článku na www.idnes.cz (Krutil 2013).

26 Sochár, s ktorým sme robili rozhovor, mal na Zbrojovke desat' rokov ateliér a $\mathrm{v}$ rozpore $\mathrm{s}$ našimi pôvodnými očakávaniami sa ako zástupca umelcov dostal k objektu pri hl'adaní vel'kého, lacného priestoru, fyzicky a finančne vhodného pre jeho prácu, nasledoval teda biografický projekt s ciel’om sebarealizácie, bez aktivistických či inovačných zámerov. Hodnotu Zbrojovky pre Brno v minulosti vzt’ahoval k domácemu a názorovému svetu, no spomenul aj prítomnost' okrajových príbehov o kreatívnych l'ud'och s potenciálom presadit' režimy dobra inšpiračného sveta viažuce sa $\mathrm{k}$ tomuto miestu. 
nesprávnych politických či menežérskych rozhodnutí, a vo vel'kej miere aj okolo nekalých praktík tých, ktorí Zbrojovku „rozkradli a vytunelovali““. ${ }^{27}$

Samotné obdobie prechodu na „trhový kapitalizmus“ je stále v pamäti obyvatel’ov Česka vnímané rôzne. Jedným z pohl'adov je aj nesúhlas s politickými rozhodnutiami, ktoré zmenili postavenie českého zbrojárenského priemyslu:

Odrazu prišla doba privatizácii a rozhodnutie, že my [Československo] obmedzíme radikálne zbrojný priemysel, ktorý tvoril vysoké percento svetovej výroby. Nemci sa usilovali, aby dostali náš zbrojný priemysel. [...] Jedna zo zásadných príčin bola, že sa náš pán prezident s vtedajším ministrom priemyslu Dlouhým v úvodzovkách pochlapili, a podarilo sa im rozbit' RVHP. (Aktivista)

Iní zas videli v konci štátom riadeného podnikania nádej na rozvoj kreatívneho potenciálu miestnych technikov:

Ja sa snažím na to nemysliet'. Ak by ste spomínali na to, čo ste tu všetko zažili, už tu dávno nemôžete byt', lebo vám to príde ako plno stratených šancí a možností, čo tu mohlo byt'. Nemyslím od revolúcie a d'alej, ale tu sa naozaj už vtedy dali vyrábat' veci, ktoré by asi boli predajné po celom svete. Ale tak, ako máme teraz EU a neviem čo všetko, vtedy bol inštitút RVHP a ten vám to vrátil naspät'. A povedali: „Nie nie, to nebudete vyrábat', to už vyrábajú tamtí,“ a tým vám tie krídla zas trochu pristrihli a odletiet' sa nedalo. (Správca Zbrojovák) ${ }^{28}$

Prvotnou emóciou u niektorých zamestnancov Zbrojovky tak po nástupe nového politického a ekonomického systému bola nádej, že podnik bude za pomoci nových technológií napredovat'.

Tak sme to pomocou tej výpočtovej techniky t’ahali hore pekne. A potom prišiel ten osemdesiaty deviaty rok, a všetko sa to zlomilo. Urobili sa vel'ké zmeny, organizačné zmeny. Skvalitnila sa výpočtová technika, rozbehlo sa to celkom sl’ubne po všetkých divíziách a tak, ale nemalo to vel'mi dlhé trvanie, pretože jednotlivé divízie, nechcem povedat', že krachovali, ale potlačili výrobu, takže neboli potrební l’udia, až to šlo postupne úplne do nuly. (Správca Zbrojovák)

Tieto porevolučné organizačné zmeny zahŕňali založenie akciovej spoločnosti s troma divíziami a zrušenie niektorých „,neperspektívnych výrobných odborov“, počet pracovných síl sa znížil z 10500 v roku 1990 na necelých 2500 v roku 1993. Okrem obmedzenej strojárenskej výroby sa pokračovalo vo výrobe zbraní, z ktorých 90 \% mierilo na zahraničný trh. Koncom 90. rokov však Zbrojovka už dlžila miliónové čiastky a vedenie vykonalo z pohl'adu našich komunikačných partnerov radikálne kroky.

27 Slovné spojenie vyskytujúce sa vo výpovediach viacerých komunikačných partnerov.

28 Komunikačný partner tak naznačuje, že práca v Zbrojovke by mohla byt' aj kreatívnou činnost'ou a považuje za negatívne, že k presadeniu tvorivosti vo vývoji a výrobe nemohlo vzhl'adom na centrálne plánované hospodárstvo dôjst'. V jeho argumente sa tak v tomto prípade objavujú režimy dobra vlastné kreatívnemu svetu. 
Ťažko sa to chápalo, prečo $\mathrm{k}$ tomu došlo, prečo sa to rozprášilo behom jedného roka, prestalo to existovat' a ostalo tu pár l'udí. [...] Odrazu prišiel niekto a povedal, ja už t’a nepotrebujem. A oni sami vedeli, že majú nejakú cenu, a nechápali, ako je možné, že už ich nikto nechce, nepotrebuje. Tak z tých dôvodov, kl’udne poviem, že aj radi odišli, pri tej predstave, čo sa tu bude eventuálne diat'. (Správca Zbrojovák)

Práve to, čo sa eventuálne malo diat', mnohí respondenti i média nazývali „vytunelovaním“. V roku 1999 bol prvýkrát navrhnutý konkurz, Zbrojovka sa rozštiepila na d’alšie dcérske firmy a behom nasledujúcich rokov sa predali akcie, ale aj strojné vybavenie, ktoré sa v následných konkurzoch už nepodarilo dohl'adat'. ${ }^{29}$

Strata a predaj vel'kej časti vybavenia boli určite jedným z dôvodov, prečo bolo obnovenie pôvodnej výroby po vysporiadaní majetku t’ažko uskutočnitel'né. Následné plány o využití toho, čo Zbrojovka kedysi ponúkala na rozbehnutie podnikania, tak už boli odkázané na neúspech.

To, že l’udia postupne odchádzali, bolo smutné, nie z osobného hl'adiska, ale vraveli sme, že je to hlúpost', za pár rokov to niekto bude chciet' vrátit' spät', ale už nebude čo... Za pár rokov prišli podnikatelia a vraveli, vy ste tu vyrábali kedysi pekné malé veci, prečo to nerobíte? No tak, výroba prestala, všetko sa vyviezlo do šrotu, stroje sa predali. A oni vraveli, my by sme vás teraz nosili na rukách, my to kupujeme za t’ažké peniaze, a od vás to bolo v rovnakej kvalite a za iné prachy. (Správca Zbrojovák)

Vo výpovediach bývalých zamestnancov je zretel'ne prítomná aj l'útost' nad neschopnost'ou zorganizovat' sa, celkovo je ukončenie výroby v Zbrojovke vnímané ako stratená príležitost'.

Myslím, že ak by sa v tej dobe niektoré prevádzky, neviem, možno to nešlo, neviem, sprivatizovali a urobil by sa dobrý marketing, tak sa určite tie dielne dali zachránit'. Ten prerod, že skončili a prišli podnikatelia a hovorili, áno, potrebujeme to, medzi tým boli dva roky. [...] Asi v tej dobe, $\mathrm{v}$ tých devät'desiatych rokoch, nebola tá manažérska zložka na takej úrovni, aby to dokázali tak

29 Tento príbeh vytunelovania má v rozprávaní našich respondentov svoje hlavé postavy: V apríli roku 2000 zamestnala Zbrojovka Brno a.s. bez výberového konania ako riaditel’a odboru vonkajších vzt’ahov Vasila Mohoritu. Mohorita bol významným predprevratovým funkcionárom politických štruktúr tých čias, pôsobil ako šéf Socialistického zväzu mládeže (SSM/SZM) a po roku 1989 pokračoval v politickej kariére $\mathrm{v}$ rámci KSČ a neskôr v d'alších stranách. Jeho meno sa dokonca ozývalo aj v protestných sloganoch v novembri 1989, „Mohorita od koryta!“, a pre mnohých je dnes ikonou zákulisnej moci, ktorú si prednovembrový aparát zachoval. Mohoritu ako symbol zániku Zbrojovky spomenuli viacerí respondenti, ktorí si tú dobu pamätajú: „Tak Zbrojovka odrazu začala chátrat'. Tie firmičky, čo tam boli... O to sa jeden čas staral aj Mohorita, vysoký funkcionár, ktorý sa potom vrhol na toto. Nepoznám presne jeho úlohu, ale viem, že to šlo proste ku dnu.“ „Zbrojovka-fabrika je vytunelovaná, nejaký Mohorita, ak vám to niečo hovorí, tak ten sa na tom podiel’al a nejaká firma z Ústí nad Labem, tí to nejakým spôsobom vytunelovali... Nechcem povedat', že to bolo vytunelované, ale nebolo to úplne fér a kóšer." Okrem Mohoritu je s kauzou vytunelovania Zbrojovky vo výpovediach ako „antihrdina“ spájaný aj sudca Berka, ktorý vyhlasoval konkurz v roku 2003, a správkyňa konkurznej podstaty, ktorá bola odsúdená za predaj zbraní v majetku Zbrojovky pod cenu, ale aj všeobecne označení „špekulanti a ich kamaráti“. 
ošetrit', aby povedali, to nevadí, že sa to zatvára, ja si teraz prenajmem u nejakého súkromníka garáž a ja si tam ten stroj dám a budem pokračovat' na tej práci tam a uvidíme, za pár rokov sa možno aj dostanem spät’ do tej dielne, kde som robil. Ale vtedy sme toto ešte nevedeli. (Správca Zbrojovák) $)^{30}$

Podnikatel'ské aktivity, ktoré v areáli dnes v menšej miere prebiehajú, majú so „zbrojováckou slávou a hrdost'ou“ pre oslovených aktérov málo spoločné. Majitel'ovi, ktorý zamýšl’a Zbrojovku po zlepšení ekonomickej situácie zbúrat' a prestavat' na novú mestskú čast', areál spravuje firma, ktorá zabezpečuje jeho údržbu a prenajímanie priestorov. Polovica slúži ako sklady, čast’ sú dnes kancelárske priestory a výroba je minimálna. O priestory v centre Brna je stále záujem, správca a zároveň bývalý zamestnanec továrne podl’a vlastných slov za mesiac jedná s

desat', pätnást' l'ud'mi, ktorí zháňajú miesta nie na prácu, ale na podnikanie a chcú sto metrov dielne. Poviete, do tej dielne prší. A on povie, no, tak to opravte nejako, ja to beriem. Vymal'ujte to, urobte mi strechu, spravte mi sociálky. Už ale neberie tú druhú stránku veci, že my sme v tom mantineli od toho majitel'a, ktorý povie „nie, ja do toho nechcem vrážat' peniaze. [...] Že raz, až dôjde čas, my z toho niečo urobíme." Je to lukratívny pozemok uprostred Brna, s tým by sa dali robit' pekné veci. Ale t’ažko vám niekto vyčlení balík peňazí na to, aby ste to nejako vrátili. (Správca Zbrojovák) ${ }^{31}$

Z jeho strany je teda prítomná určitá rezignovanost' a uvedomovanie si nemožnosti naštartovat' výrobu v súčasnej situácii, kedy majitel' vyčkáva a z prenájmov pokrýva náklady, ktoré vznikli vydražením tohto areálu.

Možnou motiváciou vedúcou k rozsiahlejšej úprave priestorov zo strany nájomcov by mohol byt' osobný vzt'ah, pretože aj napriek finančnej náročnosti, ,ak by prišiel nejaký bývalý zamestnanec, čo tu robieval, ten by do [tej rekonštrukcie priestorov] šiel len pre tie spomienky, ako to bývavalo“. Takúto situáciu však už Správca Zbrojovák považuje za viac-menej nereálnu, pretože títo nositelia osobného príbehu o vel'kosti Zbrojovky „už v podstate nežijú“, prípadne „sú v dôchodku, a majú iné starosti a problémy, než tu niečo takto rozbiehat"، Táto potenciálna motivačná sila vedúca ku konaniu, ktorú by generovali spomienky na slávu Zbrojovky, teda nijak nezasiahla a už ani nezasiahne do otázky obnovenia výroby. Jediná čast' rôznorodej strojárskej výroby, ktorá ostala a zamestnáva aj bývalých pracovníkov Zbrojovky, je výroba zbraní v malom.

Výroba zbraní pod dcérskou firmou brnenskej Zbrojovky skončila v roku 2006 a nový správca konkurznej podstaty na verejnej dražbe predal obrábacie centrá a čast' d'alšieho

30 Hoci sa dnes Správca Zbrojovák vzt’ahuje k Zbrojovke ako k svojej každodennosti, v tejto výpovedi naznačuje l'útost' nad tým, že nikto nebol schopný kreatívneho, inovatívneho konania, ktoré by výrobu zachránilo, aj ked' pracovníkov za kreatívnych a vynaliezavých považoval. Manažérsky schopné konanie, ktoré spomína, by bolo možné, ak by v tej dobe boli prítomné profesionálne kompetencie z priemyselného sveta.

31 Je zaujímavé, že tento dnes prenajímaný priestor stále označuje slovom dielňa, ako v časoch výroby. Zmenilo sa síce využitie hál, ale ich pomenovania ostávajú pre l'udí, ktorí v areáli pracovali, hlboko vžité. 
strojového vybavenia firme Brno Rifles, ktorá pokračuje vo výrobe časti zbraní pod slávnou značkou Zbrojovky Brno, patrí však už pod Českú zbrojovku Uherský Brod. Výroba prebiehala v zábrdovickom areáli, kvôli chátraniu priestorov sa však presúva na iné miesto. Majitel' na svojich stránkach ale zdôrazňuje, že chce byt' stále súčastou brnenskej zbrojováckej tradície: „Uskutočnil sa výber vhodnej lokality, ktorú odsúhlasili nadriadené orgány spoločnosti. Slávna tradícia Zbrojovky bude teda pokračovat' - a to V BRNE.“" 32

V malom teda tradícia brnenského „zetka v krúžku“ pokračuje d’alej a dokonca sa hlási $\mathrm{k}$ historickému odkazu slávneho podniku. Tento fakt $\mathrm{v}$ sebe nesie potenciál pre kultivovanie pamäte spojenej s industriálnou minulost'ou mesta, aj vd’aka tomu, že pre súčasných vedúcich firmy je zjavne dôležité prepojenost' s pôvodnou Zbrojovkou a jej umiestnením v Brne akcentovat'. V konečnom dôsledku teda táto firma bude odkazovat' k pamäti o Zbrojovke, či už je jej zámer postavený na dôvodoch finančných a marketingových typických pre trhový svet, alebo ide zo strany zodpovedných o lokálny patriotizmus či nostalgiu, cenené v rámci sveta názorového. Hoci tí, ktorí pamätajú slávne dni Zbrojovky, podnik ako následníka neoznačovali, predovšetkým kvôli vel’mi obmedzenému zameraniu v porovnaní s predrevolučnou výrobou, v budúcnosti je možnost', že príbeh o stratených šanciach ustúpi do pozadia a výroba zbraní v menšom pod uherskobrodskou taktovkou bude chápaná ako legitímny nástupca predrevolučnej slávnej vel'kovýroby.

\section{Príbeh štvrtý: Zbrojovka súčastou developerského plánu}

Celkový úpadok výroby a areálu viedol k tomu, že miesto slávnej továrne sa začalo menit' na miesto výhodnej nehnutel'nej investície: „.... ked' to bolo v takom stave, akože zlom, tak sa o to začali zaujímat' developeri, pretože tá lokalita je zaujímavá..." Posledný konkurzný správca nakoniec predal zvyšný majetok vrátane samotného areálu Zbrojovky. Dražba za rekordných 707 miliónov korún pokryla dlžoby veritel'om a developer, ktorý areál kúpil, vyhlásil svoj zámer zbúrat' budovy a postavit' novú mestskú čast'.

Ako sa ukazuje, práve tento moment rozhodnutia o zbúraní mal v sebe mobilizačný potenciál a toto zistenie viedlo nášho komunikačného partnera $\mathrm{z}$ občianskeho združenie Židenice pro občany k aktivite smerujúcej k zachovaniu časti areálu. Samotná dražba a predaj Zbrojovky teda ešte neboli dostatočným dôvodom, aby sa l'udia začali o Zbrojovku viac zaujímat', ako náhle však hrozilo úplné vymazanie areálu z mapy Brna, hodnoty technologického a historického dedičstva vystupujú u časti aktérov do popredia a sú nimi ozmyselňované.

Nejakú dobu to [po dražbe] ležalo, bolo „ticho po pěšině“, a potom sa [investor] rozhodol, že spracuje projekt a prebuduje to na bytový komplex. V tej chvíli ked' sa o tom začalo hovorit', mne to vadilo, lebo za prvé zanikne industriálny priestor, kde je vel'a vecí cenných ako z hladiska stavebného, tak aj historického. Poviem to takto: na tých halách bolo použitých plno konštrukcií, ako šiel stavebný vývoj, ktoré sú svojim spôsobom zaujímavé, je vidno, ako šiel historický vývoj.

32 História vzniku spoločnosti Brno Rifles, dostupné na webových stránkach Zbrojovky Brno (Zbrojovka 2013). 
Tam sa mal spravit' stavebne historický prieskum, bohužial' sa mi to nepodarilo presadit' ani cez to občianske združenie. (Aktivista) ${ }^{33}$

Od tohto momentu teda preberá OZ Židenice pro občany akýsi patronát nad bojom o fyzickú podobu dedičstva Zbrojovky a jeho zástupcovia sa aktívne zasadzujú o pripomienkovanie oficiálnej dokumentácie ohl'adom prestavby. Hlavným dôvodom obáv združenia bolo, že povolenie k búraniu bolo vydané ešte pred spracovaním projektu budúcej zástavby, čo považovali za nelogické a z hl'adiska zachovania pamäti miesta a ochrany objektov i potenciálne nebezpečné:

Postup pri realizácií projektu prestavby areálu Zbrojovky, kedy majú byt' najprv zlikvidované všetky objekty a potom spracovaná dokumentácia novej výstavby, je v rozpore so stavebným zákonom. Najprv by mala byt' spracovaná variantná štúdia, ktorá by umožnila posúdit', ktoré objekty by mali byt' zakomponované do novej výstavby, ako pamät' miesta a pripomienka kontinuity osídlenia, a ktoré zbúrané. (Aktivista) ${ }^{34}$

$\mathrm{V}$ rámci pripomienok $\mathrm{k}$ búraniu celého areálu združenie pripojilo aj svoj komentár s návrhom využitia jednotlivých stavieb pre účely športu či kultúry, navrhovalo vytvorenie múzea, kritizovalo napríklad aj demoláciu vojenských krytov kvôli zabezpečeniu obyvatel'stva v čase vojnového konfliktu či požadovalo maximálne ekologicky opatrný postup pri demolácií budov, ktoré sa zachovávat' nebudú. ${ }^{35}$

OZ Židenice pro občany vyjednávalo o zachovaní čo najväčšieho počtu budov ako materiálnej pripomienky Zbrojovky aj počas tvorby návrhu budúceho využitia areálu. Podl'a slov architekta, ktorý na projekte pracoval, však bolo už od začiatku aj bez pričinenia občianskych aktivistov zámerom nevytvorit’ priestor typu „Manhattanu s mrakodrapmi“, ale priestor „,s typológiou európskeho mesta s ulicami, námestiami a domami normálnej výšky“. Čo sa týka zachovania budov v areáli, architekti vytipovali objekty hodné zachovania podl'a vlastného uváženia. Vzhl'adom k neexistencii pamiatkovej ochrany, ktorej ustanovenie opakovane navrhovalo OZ, sa však neriadili čisto historickou hodnotou jednotlivých stavieb. Nakol'ko bol projekt zadaný za účelom umiestnenia najmä bytových či kancelárskych jednotiek, na ktoré sa podl'a architekta industriálne budovy v Zbrojovke využit’ nedajú, technické a estetické parametre boli dôležité:

[...] pokial' tam má vzniknút' úspešná čast' mesta, úspešná v tom, že tam budú l’udia, že tam budú radi, že tam bude bezpečne, že si to kúpia za vel'mi drahé peniaze a budú si to vážit', budú sa o to starat', tak tam tie haly proste byt' nemôžu. Pretože tam nemôže kooexistovat' kvalitné moderné mesto normálne s ulicami, so všetkým, a tieto haly. Keby boli tie haly inej vel'kosti a inej štruktúry, tak by to išlo, ale tým, že sú to haly vojenské a extrémne nízke a extrémne široké, tak sú nepoužitel'né. A tie haly, ktoré sú vysoké, tak sú zase šeredné. (Architekt)

33 Toto je ideálny prípad režimu dobra typického pre občiansky svet, kedy kolektívny záujem vedie Aktivistu k inštitucionalizovanému konaniu smerujúcemu k spochybneniu zdiel'aného dobra sveta trhového, ktorý je pre Aktivistu zosobnený developerom.

34 Vid' Občanské sdružení Židenice pro občany (2008).

35 Dôležitost' zachovania toho, čo Aktivista považuje za pamiatku, môžeme chápat' ako zakotvené v občianskom, ale vzhl’adom na pripomínanie slávy Zbrojovky a vlastného mesta, tiež názorovom svete. 
So zachovaním materiálneho odkazu k minulosti však návrh počíta, musí však byt' citlivo zakomponovaný do novej výstavby:

[...] skupina výškových budov okolo hlavného námestia vytvárajúca znak novej štvrte dáva tiež v širšej mestskej krajine jasný signál o novej výstavbe a zároveň ul'ahčuje celkovú orientáciu. Nie je pritom umiestnená na styčnej línii s historickou štruktúrou. Tá je naopak smerom k mestu tvorená existujúcimi objektmi - bývalým riaditel'stvom Zbrojovky a objektom Beranovej továrne. Ponechané staršie stavby dávajú územiu jeho historickú vrstevnatost' a pamät'. (Architekt) ${ }^{36}$

Komunikácia OZ Židenice pro občany s architektonickou kanceláriou po zverejnení stavebného projektu nebola intenzívna, týkala sa predovšetkým zachovania objektu barokového zámočku v areáli. Architekt:

My sme boli v kontakte s niektorou z ich organizácií, z nejakou z tých občianskych aktivít, a tí chceli, aby tam bol zachovaný barokový zámoček. Tam teda žiaden barokový zámoček nie je, pretože tá budova je tak zničená, že nikto nespozná, že tam nejaký barokový zámoček je. Ale priali si ho zachovat' a my sme to prepracovali, takže sme náš projekt prepracovali a ten objekt zámočka sme tam zachovali. To už nie je zámoček, to je normálna taká budova, kde sú staré základy stien.

Tento konflikt ohl'adom zachovania budov poukazuje na rôzne spôsoby vnímania dôležitosti fyzického aspektu historického dedičstva. Architekt spoluvytvárajúci návrh novej Zbrojovky, ktorý o sebe povedal, že je ,vel'mi konzervatívny človek a nechce inováciu pre inováciu“, považuje za dostatočnú pripomienku zachovanie prvorepublikovej administratívnej budovy a niekol'ko málo výrobných budov s vhodnou mierkou pre plánované nové využitie.

Na druhej strane aktivista vidí v zámočku budovu so silným historickým odkazom, kvôli významnosti architekta, ktorý ho pred stovkami rokov navrhol. Ciel'om aktivistu bolo, ako sa zdá, zachovat' zo Zbrojovky všetko fyzické, čo sa zachovat’ dá. Objekt zámočku sa stal hlavným bodom, o ktorom nakoniec vyjednávali a dohodli sa, zámoček architekt do plánov zakomponoval. Aktivista však stále cíti, že konania dobre nedopadli, pretože v nich chcel pokračovat' a vyjednávat' zachovanie d'alších objektov:

Architekt sám presadzoval, aby sa určité objekty zachovali. Toto považujem za cenné. Snažili sme sa urobit' schôdzku, dal mi najavo že áno, zorganizoval tú schôdzku, ale že už sa nechce tým d'alej bavit', aby som ho nezat'ažoval [tým], že on bude d'alej organizovat' nejaké schôdzky ohl'adom Zbrojovky. Tak to dopadlo tak, ako to dopadlo. (Aktivista)

Ďalšie vyjednávania mimo témy zámočku už teda neprebehli, architekt spomínal, že združenie diskutovalo len o zachovaní zámočku a oni ako architekti „,mohli reagovat' len na to, čo oni navrhovali““.

36 Argumentácia architekta angažujúceho sa na projekte novej podoby Zbrojovky ako na individuálnom biografickom projekte s prísl’ubom sebarealizácie je tak ukotvená minimálne v dvoch Boltanského svetoch. Na jednej strane považuje za dôležitú historickú kontinuitu a pamät’ miesta, režimy dobra uznávané v domácom svete, na strane druhej tie sú však podriadené funkčnej prepojenosti a logike usporiadania a využitia (priemyselný svet). 
Táto aktivita snažiaca sa o zachovanie fyzična Zbrojovky pre niekoho môže pôsobit’ až nezmyselne:

Neznášam občianske združenia. My tu s tým bojujeme každý deň. To sa tu tak zvrhlo, že tí občania bez toho, aby mali nejaké informácie, bojujú proti všetkému. V Brne je taký systém, že tie občianske združenia chcú zachovat' status quo. Nechcú nikdy nič nového, aj keby tam mali liezt' blatom, oni radšej budú liezt' blatom, než si tam dat' asfalt ako niečo nové. [...] To je nezmysel, čo oni požadujú. [...] Tak čo sme skanzen? Nie, my potrebujeme žit', my potrebujeme pracovné príležitosti, mat' bývanie, mat' verejné priestory, a tí l'udia sa tu musia cítit' dobre. A to nie sme schopní v skanzene. To opakujem kade chodím, ale bohužial' tie občianske združenia to nechcú počut'. [...] Ked' prídem do Brna, tak chcem vidiet', ako to vyzeralo pred mnohými rokmi? To určite nie. (Úradník)

Zástupca úradníctva mesta argumentuje ako technik a plánovač, ktorý s objektmi v meste pracuje inštrumentálne, budovy majú mat' jednoznačnú funkciu a majú pôsobit’ reprezentatívne, ako „V druhom najväčšom meste Českej republiky“.

...Dnes vieme, že z hl'adiska teórie, koncepcie kompaktného mesta, je žiaduce, aby tie brownfieldy vymizli z centra mesta a aby sa v centre mesta venovali funkcii, ktorú majú mat', funkcia spoločenská a verejný priestor. (Úradník)

Odmieta mesto ako skanzen, čo je podl'a neho ciel'om prezervacionistických snáh aktivistov a pamiatkarov, pretože ak ide človek do priestoru skanzenu, ,prejde tou bránou naladený tak, že chce vidiet', ako to vyzeralo pred mnohými rokmi“. Oproti tomu stavia „,beh dvadsiateho prvého storočia, ktorý sa deje za ohradou skanzenu“, a nechce mat' jeden skanzen vedl'a druhého, pretože ,je väčší dopyt po dvadsiatom prvom storočí ako po skanzene“. ${ }^{37}$ Robí jasnú deliacu čiaru medzi historickým a súčasným, a ,ak si chcem urobit’ obrázok, ako to vyzeralo, pôjdem do múzea mesta Brna“.

S ohl'adom k zachovaniu pamäti industriálnych miest v Brne chápe prezervacionistické snahy ako nezmyselné, pretože sa emocionálne putá či historický a občiansky význam, ktoré so Zbrojovkou spájajú iní aktéri, nestretávajú s režimami dobra trhového a priemyselného sveta, ktoré orientujú jeho chápanie situácie. To súvisí s formou jeho zapojenia do sveta, teda $\mathrm{s}$ jeho snahou presadzovat' zdiel'ané dobro tak, ako ho vidí on, pričom ho k tomu legitimizuje jeho postavenie úradníka, ktorý je za toto dobro zodpovedný: „Som Brňák a mám tu isté domovské právo, a tak chcem ochraňovat' hodnoty toho Brna.“

\section{Príbeh piaty: Zbrojovka na ceste ku kultúrnemu brownfieldu}

Nízke nájmy nepoužívaných priemyselných priestorov s vel'kou rozlohou v blízkosti centra prilákali do areálu Zbrojovky aj početnú umeleckú komunitu. Spôsob, akým prišli do kontaktu so Zbrojovkou, popisujú umelci aj takto:

37 Je zaujímavé, že v rámci tejto trhovej argumentácie nijako nehovorí o kombinovaní skanzenovosti a 21. storočia, ale chápe ich ako dva póly, ktoré sa nemiešajú. Inde zas hovorí o tom, ako je historická čast' Vaňkovky doplnkom, oddychovým miestom počas nakupovania. 
[...] obchádzala som všetky možné ponuky, areály, čo som kde videla nejakú inzerciu, pýtala som sa, chodila som na obhliadky... Normálne, klasika, realitná činnost'. V Zbrojovke mi ponúkli priestor, ktorý sa mi páčil: bol vel'ký, svetlý, blízko bydliska. Ešte som mala iné ponuky, ale toto bolo aj cenovo dobré. V podstate klasická realitná činnost'. Blízkost', dostupnost'... (Maliarka) ${ }^{38}$

Viacerí komunikační partneri, ktorí v Zbrojovke pôsobili dlhodobejšie, však vzápätí dodávajú, že aj ked’ historická hodnota a génius loci budovy neboli prvotným dôvodom, prečo sa rozhodli prest'ahovat' svoju tvorbu do Zbrojovky, postupom času si špecifickú atmosféru areálu oblúbili a nechali sa ňou inšpirovat': „Úplne som sa tam do toho zamilovala. Za tie posledné dva roky som sa snažila tej Zbrojovke venovat' tak, že som si ju vzala ako motív. Volalo sa to Posledné dva roky, nevedela som, že sa to ešte predĺži o d'alších X rokov, to sme samozrejme netušili." ${ }^{39}$

Od roku 2009 sa do Zbrojovky prest’ahovalo divadlo Sedm a půl známe aj pod názvom Zbrojovka a půl, čím začalo obdobie, ktoré jeden z oslovených umelcov nazval „rozkvetom umeleckých aktivít v Zbrojovke“. Pod vedením brnenského divadelníka a režiséra bola v tej dobe sprístupnená hala č. 7, kde spomínaný divadelník ,ponúkal možnost’ organizovania skoro čohokol'vek, on to chápal ako takú klubovňu, kde mladí l'udia, nejakí kreatívni, ktorí niečo robia, niečo organizujú aktívne, takže by tam mohli realizovat' nejaké produkcie“،.

Umelecký priestor $\mathrm{v}$ Zbrojovke sa teda sčasti profiloval ako priestor pre nezávislú tvorbu a začínajúcich umelcov a viacerí komunikační partneri vyzdvihli jeho prínos pre brnenskú alternatívnu kultúrnu scénu:

V tom bola tá najväčšia sila, alebo devíza Zbrojovky, že mohol ktokol'vek príst' a pokial' to nebola úplná hovadina, tak sa mohol úplne rozumne [...] dohodnút' a spravit’ tam, čo chcel. [...] A mnoho vecí sa tam nejako zabehlo a myslím, že to dost' prospelo miestnej kultúrnej scéne, fungovalo to ako také bariérové pásmo, kultúrne, ked' niekto niečo mal chut' usporiadat', tak sa vlastne o to mohol tam pokúsit' a väčšinou to fungovalo. (Organizátor) ${ }^{40}$

V Zbrojovke prebiehali aj väčšie podujatia, napríklad niekol'ko ročníkov festivalu BurningBeats, StarobrnoFest či Factory Fashion Market, a konali sa tu koncerty mnohých domácich i zahraničných interpretov. Celkovo sú však v areále host’ované zväčša produkcie súčasnej elektronickej hudby, ktorá rozhodne nepatrí k mainstreamu. Umenie tak nie je automatickou asociáciou Brňanov, ked’ sa spomenie meno Zbrojovky, a povedomie o židenickom areáli ako o mieste kultúry je podl’a jednej zo zbrojováckych umelkýn̆ prítomné len vo fanúšikovských komunitách: „Budú to špecifické skupiny, pretože ja sa vždy o takej akcií

38 Maliarka sa k problematike Zbrojovky dostala v rámci riadenia svojej biografie, jej odkazovanie k Zbrojovke ako k objektu trhu sa zmenilo na vzt’ah emócií a inšpirácií, nerozhodla sa vstúpit' do konfliktu a bojovat' za jej záchranu, prest’ahovanie sa do iných priestorov bolo d’alším biografickým projektom.

39 Komunikačná partnerka naráža na fakt, že nájomná zmluva k ateliéru bola na dobu určitú (dva roky) a v tej dobe si myslela, že po jej vypršaní dôjde k zbúraniu celého areálu.

40 Pre Organizátora bola Zbrojovka miestom s potenciálom pre vytváranie „kreatívnej platformy pre [...] konfrontovanie s ostatnými umeleckými formami“, angažoval sa teda kreatívne v rámci inšpiračného sveta. 
dozviem až ked' zistím, že už tu prebieha. Lebo inak na to nenarazím, ako na internete alebo na Facebooku. Že to je cielené na nejakú skupinu, že si dajú l’udia medzi sebou vediet'.“ O podujatiach často nevedia ani zamestnanci prevádzok fungujúcich v susediacich budovách.

V súvislosti s kreatívno-umeleckými aktivitami v Zbrojovke je vhodné položit' si otázku, nakol'ko by brnenská továreň mohla alebo môže nasledovat' trend tzv. kultúrnych brownfieldov tak, ako ich poznajú na Západe. Čast' komunikačných partnerov nielen z radov umelcov zastáva názor, že áno.

Ja si myslím, že by to mohlo fungovat. Dokazuje to aj tá prvá budova, kde sídli divadlo Zbrojovka a půl, l’udia si sem zvykli chodit', tie akcie tu bývajú úplne pravidelne, či už divadlo, alebo hudobné akcie. Tá hala má obrovský potenciál, môže tam byt' pät' stageov zároveň. (Umelkyňa) $)^{41}$

My robíme akcie, kam chodí tisíc l’udí. To, čo vždy vnímam od tých návštevníkov, je totálny úžas nad tým, aký krásny priestor tam je, ale aký je hrozne nevyužívaný. Myslím, že potenciálne by to boli zaujímavé priestory... (Divadelníčka)

V rozpore s takto artikulovanými predstavami je však súčasný vývoj umeleckých aktivít v Zbrojovke v úpadku. Ako to pomenoval jeden z organizátorov podujatí v Zbrojovke: „... no ten rozkvet, ten bol tak od toho roku 2010 do ešte tak... asi rok a pol. Teraz už to tam tak úplne nie je, ale je to hlavne preto, že už sa nikto o tú halu, mám pocit teda, moc nestará.“

Najčastejšie argumenty, ktoré zaznievali od aktérov pri vysvetl'ovaní tohto úpadku, sa teda odvíjali od nezáujmu súčasného majitel'a do areálu akokol’vek investovat', čím sa technický stav budov a situácia postupne zhoršuje a podmienky na tvorbu a organizáciu podujatí sa stávajú bojovými: „To nové vedenie teraz už vôbec neinvestuje do tej rekonštrukcie a ten areál postupne chátra a necháva sa tak sám zničit'.“

Z rozhovorov taktiež úplne zretel'ne vystupuje aj vnímanie vopred prehratého boja, ked' o zbúraní areálu je už vlastne rozhodnuté a akékol'vek snahy niečo v Zbrojovke rozbiehat' sú tak nutne ohraničené nepredvídatel'ným časovým bodom v budúcnosti, ked' sa majitel' rozhodne podniknút' prvé kroky k realizácií svojho zámeru: „Tu je to práve vel'mi problematické tým, že je to už predané a má to súkromný slovenský vlastník. "42

$\mathrm{V}$ komunite umelcov je navyše prítomné aj rozčarovanie nad prístupom mesta Brno, pretože prvotne zo strany kompetentných očakávali pri premene Zbrojovky na kultúrny priestor podporu.

41 Z rozhovoru s umelkyňou je zrejmé, že Zbrojovku vníma predovšetkým ako pevnú súčast' svojho žitého sveta, ako „miesto pre tvorbu a pre život“. Aj ked” naznačuje potrebu zachovania objektu, jej konanie nikdy neprekročilo hranicu smerom $\mathrm{k}$ angažovanosti na poli inštitucionálnom a nenabralo formu oficiálnej obhajoby zachovania objektu, ani na poli kreatívnom v zmysle iniciácie spolupráce medzi umelcami.

42 Zaujímavé je, že tento kompromis o budúcnosti objektu uzatvorený predovšetkým medzi mestom a developerom nikto z umelcov nespochybnil a nevykonal test reality založený na režimoch dobra inšpiračného sveta. Akákol'vek argumentácia ukotvená v tomto svete tak nemá dostatočný mobilizačný potenciál, aby motivovala aktérov ku konkrétnym krokom (napríklad smerujúcim ku kampani za zachovanie umelcami využívanej budovy č. 7). 
To bol ten zámer, ak sa tam vyvinie nejaká aktivita, tak to implementovat’ do tej štvrti, čo by tam bola. A vtedy bola aj taká argumentácia, že Onderka mal vo volebnom programe revitalizáciu týchto zón, že mesto tomu bude naklonené, čo sa opät' nepotvrdilo, mesto ako vždy svoje sl’uby nesplnilo, nie je ničomu takému naklonené. (Divadelníčka) ${ }^{43}$

Zo strany Úradníka sú aktivity prebiehajúce v súčasnosti v Zbrojovke vnímané s určitou rozpačitost'ou ako prechodné a rozhodne nie hodné podpory:

No, tak to je núdze cnost'. To je typická situácia, ktorá sa odohráva v celej Európe, že tie brownfieldy t’ažko hl'adajú využitie. A pretože tu sú rôzne organizácie a spolky, ktoré nemajú kam, ani nie sú žiadaní nikde, tak tie s obl’ubou využívajú tie priestory. To mate v Rakúsku, v Nemecku. Takže ked' v týchto priestoroch existujú rôzne dielne, robia sa z toho výstavné priestory a robia sa tie kultúrne [podujatia] pre ten bigbít a tieto rôzne smery, je to dobré, lebo to aspoň nájde nejaké využitie a neobt'ažuje to okolie, lebo je to odvšadial' d'aleko. Ale je to dočasná záležitost'. (Úradník)

Potenciál Zbrojovky ako miesta kultúry sa tak postupne vytráca. Aj čast' umelcov, ktorí boli v minulosti v Zbrojovke relatívne aktívni, postupne stráca o objekt záujem a ich vnímanie Zbrojovky ako výnimočného priestoru dôležitého pre brnenskú kultúrnu scénu čoraz viac ustupuje silným argumentom industriálneho a finančného sveta, v ktorých perspektíve je akákol’vek d’alšia úprava areálu okrem zbúrania vnímaná ako finančne náročná, neefektívna a nelogická.

Ja si myslím, že by bolo celkom ideálne, keby to tam zbúrali a postavili by tam niečo nového, tak ako je to oficiálne v pláne. A vzhl'adom k tomu, aká vel'ká oblast' to je, tak zachovávat' to je samozrejme absurdné, tá rekonštrukcia je hrozne drahá, pretože je to tak zdevastované tou priemyselnou zátažou, že to proste tak tiež len tak nebude... Zbrojovka je proste brownfield ako akýkol'vek iný kdekol'vek inde, akurát, že v Brne je naozaj vel'ká, tým pádom je i významná, ale na druhú stranu, že by tam bolo nejaké kultúrne dedičstvo, tak to si ako úplne nemyslím. (Organizátor)

\section{Záver: Zachovaf', či nezachovat?}

Východiskom našej interpretačnej stratégie sú teoretické predpoklady post-bourdieuovskej sociológie, podl'a ktorej by sme akty zdôvodňovania a ospravedlňovania nemali analyticky zredukovat' na spätné ,racionalizácie“ či „dovysvetl’ovanie“ volieb jednotlivcov. V tomto zmysle sme nevysvetl'ovali konanie aktérov, ktorí sa angažujú v procese ozmysel'ňovania budúcnosti areálu brnenskej Zbrojovky, ako odraz ich štrukturálnej pozície na sociálnom poli a tomu zodpovedajúcich habitusov a pravdepodobných stratégií konania. V súlade s teoretickým modelom pragmatickej sociológie sme sa sústredili na rekonštrukciu štruktúr argumentácie, aby sme porozumeli, ako môže človek dospiet' k tomu, že bude považovat' nejakú budovu alebo miesto za vhodné zachovania, alebo naopak za predurčené k zbúraniu

43 Zozačiatku bola jej kreatívna angažovanost' aj angažovanost'ou v inštitucionalizovanom konaní (vyjednávanie $\mathrm{s}$ mestom), ktoré malo viest' $\mathrm{k}$ vytvoreniu známeho, umeleckého centra v Brne (názorový svet). 
a zabudnutiu. Rekonštrukciu štruktúr argumentácie sme uskutočnili formou náčrtu typických príbehov, ktoré vychádzali z výpovedí na tomto poli angažovaných aktérov. Argumentačná konfigurácia týchto príbehov odhal'uje $\mathrm{v}$ súčasnosti prítomné podoby moralizmu a realizmu, ktoré sú aktérmi považované za relevantné vo vzt’ahu k urbánnej pamäti. Prepojenost' týchto príbehov so štruktúrou režimov dobra šiestich ideálno typických svetov nám umožňuje porozumiet' tomu, na základe akých foriem hladania dobra a realizmu sú l’udia schopní zaujat' pozíciu vo vzt’ahu $\mathrm{k}$ minulosti a budúcnosti, vrátane toho, ako je možné, že l’udia zastávajúci odlišné spoločenské pozície zdiel'ajú predstavu o potenciálnej budúcnosti, ktorá je založená na vymazaní časti minulosti z priestoru ich mesta.

Pri ospravedlňovaní toho, prečo by mala byt' Zbrojovka zbúraná, alebo práve naopak zachovaná, argumentujú aktéri z perspektív rôznych hodnotiacich svetov a zvýznamňujú v svojich rečových aktoch odlišné režimy dobra. Pri spore o budúcnost', aj ked' do určitej miery už pevne danú a podmienenú existenciou developerského zámeru a architektonického plánu, tak vychádzajú na povrch vo výpovediach aj časti príbehov, a teda pamäte, ku ktorým sa komunikační partneri vztahujú. Analyticky zaujímavým faktom je, že napriek prvotnému predpokladu relatívnej homogenity stanovísk jednotlivých skupín aktérov (umelci, architekti a úradníci z magistrátu mesta Brno, občianski aktivisti), tí sa v svojej argumentácií odvolávajú na odlišné režimy dobra nezávisle od svojej pozície v sociálnom poli a vzt’ahu k Zbrojovke. V súlade s Boltanským a Thévenotom (2006) tak môžeme popísat' argumenty našich komunikačných partnerov ako situačné a aktérov klasifikovat' nie podla skupinovej príslušnosti, ale podl'a spôsobu, akým sa k Zbrojovke vzt’ahujú.

Práve podobne situačným charakterom disponujú tiež nami rekonštruované príbehy a v nich objektivizované kompromisy medzi odlišnými režimami dobra. Môžeme si predstavit’ situáciu, v ktorej špecifický príbeh odkazuje na jediný režim dobra, kde strany sporu zdiel’ajú každodenný svet, rovnakú formu realizmu a hl'adanie dobra. V takejto ideálne typickej situácii je všetko pripravené na to, aby strany sporu mohli dôjst' ku konsenzu. Avšak nami skúmaný prípad brnenskej Zbrojovky vykazoval znaky situácie, v ktorej účastníci sporu nezdiel'ajú rovnaký každodenný svet $\mathrm{s}$ ostatnými účastníkmi sporu, ale v ktorej ich príbehy odkazujú k rôznym režimom dobra. Inak povedané, vstúpili sme do situácie, v ktorej sa ukazovala prítomnost' rôznych, vzájomne sa prekrývajúcich alebo vylučujúcich podôb realizmu a moralizmu. $\mathrm{V}$ takýchto prípadoch, ked' účastníci sporov odkazujú vo svojich argumentoch k rôznym režimom dobra, je dosahovanie konsenzu komplikované. Boltanski a Thévenot $(1999,2006)$ ukazujú, že podobne ako sa bežná forma kritiky artikuluje naprieč rôznymi režimami dobra, konsenzuálne riešenie sporov sa bežne odohráva vo forme vytvorenia kompromisu medzi týmito režimami. V tomto zmysle môže byt' príkladom bežnej kritiky situácia, ked' argumenty zdôrazňujúce rovnost', a tým odkazujúce k občianskemu svetu a jeho režimom dobra, sú kritizované z pozície priemyselného sveta ako výrazy neprofesionality. Podobne ako v prípade kritiky, vzájomná otvorenost' týchto režimov dobra umožňuje ich prepojenie aj formou kompromisov, ako napríklad medzi kreatívnym individualizmom sveta inšpirácie a vysokou hodnotou slávy v svete názorovom. Situačný charakter týchto kompromisov je daný ich dočasnost'ou, nevychádza nutne ani zo symbolickej štruktúry argumentácie ani zo štruktúry mocenských vzt’ahov medzi aktérmi sporov. Vzniká ako aj zaniká prepojením logiky situácie a inovatívnosti aktérov. 
Na základe výpovedí aktérov i analýzy dokumentov je tak súčasný status quo možné považovat' za určitý kompromis uzavretý v rámci sveta priemyselného a trhového, a teda posúvajúceho do popredia režimy dobra ako efektivita, výnosnost', pokrok a zisk. Zbrojovka, ktorá je v súčasnosti vnímaná aj ako „čierna diera v centre Brna“, tak má byt’ pretvorená na „Novú Zbrojovku“, teda novú obytnú štvrt'. Perspektívy týchto dvoch svetov sú orientované výlučne na budúcnost' a kultivácií pamäti neprajú. Napriek tomu sú však v príbehoch o Zbrojovke prítomné aj argumenty, ktoré režimy dobra priemyselného a trhového sveta odmietajú a na základe jednotlivých aspektov historického architektonického dedičstva či kultúrne-spoločenského významu obhajujú zachovanie časti objektu továrne ako miesta pamäti.

Zaujímavé je tak sledovat' práve rečové akty, ktoré sa snažia aktuálny kompromis napadnút' a posunút' do popredia režimy dobra vychádzajúce z inšpiračného sveta (Zbrojovka dôležitá pre kultúru), domáceho sveta (Zbrojovka ako významné miesto s bohatou tradíciou) či sveta občianskeho (Zbrojovka ako historicky dôležitá pripomienka doby). Tieto argumenty pôsobia voči súčasnému kompromisu ako vyzývatelia (reality test) a ohrozujú jeho trvácnost'. Ako sa však ukázalo, ich celková sila a mobilizačný potenciál sú relatívne slabé a vo väčšine rozhovorov naprieč spektrom aktérov je napriek tomuto alternatívnemu vnímaniu prítomné silnejšie či slabšie presvedčenie, že areál Zbrojovky je predsa len najlepšie zbúrat' a že „Zbrojovka je vlastne brownfield ako každý iný“، ${ }^{44}$ Aj komunikační partneri, ktorí prejavovali relatívne vel'kú mieru nostalgie za Zbrojovkou, nedokázali alebo nechceli tento pocit l'útosti nad zbúraním areálu pretavit' do konania smerujúceho k podniknutiu určitých krokov, ktoré by viedli k zachráneniu aspoň časti areálu. Tento model argumentácie pre zachovanie budov, ale aj následnej pasivity, bolo možné pozorovat' predovšetkým u časti oslovených umelcov, ktorí na jednej strane vyzdvihovali význam Zbrojovky ako kultúrneho centra so špecifickou atmosférou, na strane druhej však pasívne prijímali fakt, že areál postupne upadá a bude zbúraný a aktívnym konaním sa o jeho zachovanie nepričinili. ${ }^{45}$

$\mathrm{Z}$ hl'adiska aktívneho konania smerujúceho $\mathrm{k}$ obhajobe zachovania časti objektu sa v celom prípade objavujú dve výnimky. Prvou je architekt, ktorý sa podiel'al na vypracovávaní architektonického návrhu a zo svojho postu mal potrebný dosah na to, aby bol jeho argument o dôležitosti ponechania starších stavieb kvôli zachovaniu historickej vrstevnatosti a pamäti územia zapracovaný. Druhou výnimkou bolo OZ Židenice pro občany, reprezentované dvoma komunikačnými partnermi, ktorí síce taktiež v konečnom dôsledku prijali fakt, že vel'ká čast' areálu bude zbúraná, ale cez pripomienkovanie dokumentácie búracích prác presadzovali záchranu časti budov s najväčším historickým významom. Títo aktéri tak aj

44 Toto presvedčenie bolo zastúpené u viacerých komunikačných partnerov, ktorí Zbrojovku vnímali z nejakého dôvodu ako významnú, napriek tomu však svoje výpovede ukončili v zmysle „, konečnom dôsledku nie je nenahraditel'nác.

45 Práve kultúrne brownfieldy v západnej Európe sú špecifické relatívne vysokou mierou aktivizmu zo strany svojich ustanovitel'ov, snažiacich sa spravit' všetko pre ich zachovanie a ochranu pred potenciálnymi developerskými zámermi. Tieto aktivity väčšinou naberajú formu občianskych iniciatív „Zdola“ a v prípade úspechu často prerastajú aj v širšiu spoluprácu s mestom, vid’ napríklad Andres a Grésillon (2013). 
cez vzájomnú spoluprácu dosiahli, že čast' budov (vstupná brána s bývalým riaditel'stvom budovy, Beranova továreň popri rieke a barokový zámoček) bude implementovaná do novej zástavby a materiálne ukotvenie pamäte o Zbrojovke tak bude aspoň čiastočne prítomné aj nad'alej.

Vo viacerých rozhovoroch bola v súvislosti s osudom Zbrojovky spomenutá aj Vaňkovka, d’alšia bývalá významná brnenská továreň. Premena Vaňkovky z pohl'adu našich komunikačných partnerov slúži ako určitý pozitívnejší príklad toho, ako je možné naložit' s industriálnym dedičstvom tak, aby to bolo prospešné pre mesto, ale zároveň aby ostala aspoň z časti zachovaná aj historická a občianska hodnota objektu. ${ }^{46}$

V prípade areálu strojárenského podniku Vaňkovka došlo k zbúraniu väčšej časti areálu a vybudovaniu nákupného centra Galerie Vaňkovka na jeho mieste, ale pamät' miesta zostala nad’alej fyzicky sprítomnená v objekte historickej zlievarne, ktorá bola zachovaná a v súčasnosti slúži ako kultúrne a komunitné centrum neziskových organizácií, v objekte pôvodnej administratívnej budovy a taktiež v objekte bývalej strojárne, kde sídli galéria súčasného umenia Wannieck Gallery Brno. ${ }^{47}$ To, čo mesto Brno v spolupráci s privátnym investorom urobilo s Vaňkovkou, je tak na poli regenerácie brownfields podl'a predstavitel'ky brnenskej kultúrnej scény vnímané ako „klasický príklad dobrého zámeru“ (Divadelníčka). ${ }^{48}$

Čím sa teda líši spôsob riešenia revitalizácie a naloženia s umeleckými aktivitami a historickým dedičstvom v týchto dvoch objektoch? Aké argumenty sú používané kompetentnými osobami v situácií, ked' treba ospravedlnit', prečo jeden objekt je potrebné celý zbúrat' a z druhého je možné čast' zachovat' a využit' ho na aktivity, ktoré majú spoločenský presah?

To, že sa to podarilo, to bolo dané peniazmi. Peniaze prišli od investora, lebo si spočítal, že flek je výborný, a okrem toho, že má kšeft, tak tam môže dostat' niečo kultúrne. Lebo pozrite do všetkých nákupných centier v Brne. L'udia nevydržia nakupovat' dlho, to je tá filozofia. Oni si potrebujú oddýchnut', si pohovorit', a potom sa zas vrhnú do toho víru. A to tá Vaňkovka krásne ponúkla tým, že ja vypadnem z toho skla, obchodov, neustálej ponuky, to je únavné, vyjdem von, sadnem si do kaviarne, ktorá má úplne iné prostredie, dýchne na mňa niečím iným a ja sa vrátim a hurá, zas sa ponorím do blata tých obchodov. Takže by som povedal, že Vaňkovka je klasická ukážka dobre zainvestovaných peňazí, kde sa podarilo vytvorit' výborný nákupný priestor, kde sa podarilo zachránit' akýsi starý areál... (Úradník).

46 V objekte továrne pôsobila koncom 90. rokov Nadace Vaňkovka a neskôr Občanské sdružení Vaňkovka, ktoré organizovalo v areáli kultúrne akcie a neskôr sa spolupodiel'alo na vytvorení centra pre neziskové organizácie v objekte starej zlievarne, vid' webové stránky Slévarny Vaňkovka (Slévárna Vaňkovka 2005).

47 Viac informácií vid’ webové stránky Slévarny Vaňkovka (Slévárna Vaňkovka 2005).

48 Komunikačná partnerka však vzápätí dodáva: „aj ked’ dopadlo to, ako to dopadlo“, čim reaguje na udalosti z marca 2013, ked' mesto vypovedalo Wannieck Gallery zmluvu a hrozilo vyst'ahovanie celej galérie, a poukazuje tak na fakt, že ani v prípade Vaňkovky nie je isté, či bude kultúrne-občiansky presah zachovaný. Vid' napríklad článok „Skončí brněnská Wannieck Gallery?“ (Nekompromisně 2013). 
Výpoved’ úradníka tak vychádza jasne z režimov dobra uznávaných v svete trhovom, ktorý do popredia stavia finančnú efektivitu a zisk. ${ }^{49} \mathrm{~V}$ rámci trhového sveta zohrávajú pri rozhodovaní o osude objektu významnú úlohu peniaze a ekonomická výhodnost', práve tie určujú, čo je a čo nie je výhodné zachovat'. Dôležitost' Vaňkovky z hl'adiska kontinuity a pamäti miesta tak nie je $\mathrm{v}$ argumentácii tohto sveta vnímaná ako významná sama o sebe a aj ked' je súčast'ou kompromisu o budúcnosti objektu, nachádza sa tam iba z dôvodu, že je $\mathrm{s}$ ňou narábané ako s potenciálnou pridanou hodnotou $\mathrm{k}$ obchodu a marketingovou devízou.

Tento model je v kontexte výskumu o Zbrojovke dôležitý, pretože ukazuje, že pamät' miesta môže pretrvávat' a ostat' materializovanou v relatívne silnej forme aj na miestach, kde jej kultivácia nie je prioritou. Avšak len za predpokladu, že praktiky podporujúce jej tvorbu budú vhodne zakomponované do celkového kompromisu nad premenou objektu. ${ }^{50}$

Práve z hl'adiska tvorby takéhoto kompromisu je vhodné podotknút', že prípad Vaňkovky sa od Zbrojovky líši ešte jedným, a to relatívne významným, spôsobom: existenciou nadácie a neskôr občianskeho združenia Vaňkovka, ktorých zástupcovia sa aktívne podiel’ali na rokovaniach $\mathrm{s}$ mestom a developerom o budúcom osude objektu. ${ }^{51} \mathrm{~V}$ prípade regenerácie Vaňkovky sa tak objavuje prvok širšej spolupráce medzi širokým spektrom zainteresovaných aktérov, ktorý v prípade Zbrojovky až na drobné výnimky nie je možné vypozorovat'.

Interpretačná stratégia pragmatickej sociológie nám umožnila ukázat', ako sú praktiky formovania priestorov urbánnej pamäti prepojené s kultúrnymi predpokladmi argumentácie. Okrem odhalenia vplyvu týchto argumentačných predpokladov v situáciách ospravedlňovania nás však táto perspektíva viedla tiež $\mathrm{k}$ tomu, aby sme si všímali dôležitost' inovatívneho prístupu sociálnych aktérov, a to ako pri riešení sporov pomocou tvorby kompromisov medzi jednotlivými režimami dobra, tak pri vymýšlaní nových foriem kooperácie medzi rôznymi podobami angažovanosti $\mathrm{v}$ danej oblasti sporu. Načrtnutím štruktúry bežných foriem ospravedlňovania $\mathrm{v}$ podobe šiestich režimov dobra nám pragmatická sociológia poslúžila tiež k tomu, aby sme si uvedomili, že pre nami skúmaný prípad je charakteristická aj neprítomnost' určitých foriem argumentácie a kooperácie, napríklad taká, ktorá by viedla $\mathrm{k}$ väčšej spolupráci medzi aktérmi vo veci Zbrojovky sa angažujúcimi.

Perspektíva pragmatickej sociológie nám taktiež umožnila ukázat' všeobecne platnú prepojenost' sociálneho konania a situácií ospravedlňovania $\mathrm{s}$ materialitou sveta. Prípad Zbrojovky, procesu formovania urbánnej pamäti, demonštruje, že situácie ospravedlňovania, spory a argumenty, sa neodohrávajú len na úrovni špekulatívnych debát, ale v úzkom vztahu $\mathrm{k}$ materialite objektov. Inak povedané, spôsoby sprostredkovania vzt'ahu k objektom, k materialite reality, sú súčast'ou evaluačných sporov, pričom vyjednávanie týchto podôb realizmu

49 Vlastníkom historickej administratívnej budovy a strojárne je akciová spoločnost' Jižní centrum Brno, ktorej 100\% akcionárom je Mesto Brno a vlastníkom zlievarne a pozemku, kde v súčasnosti stojí nákupné centrum, je nemecká investičná spoločnost' ECE. Vid’ webové stránky Areálu Vaňkovka (Slévárna Vaňkovka 2005).

s0 Z hladiska povahy kompromisu sa tak jedná o inovatívne konanie prekračujúce hranice toho, čo je $\mathrm{v}$ jednotlivých svetoch považované za dobré a morálne.

51 Stručný popis aktivít, ktoré iniciovala Nadace a neskôr Občanské sdružení Vaňkovka, je zverejnený na webových stránkach Slévarny Vaňkovka (Slévárna Vaňkovka 2005). 
a moralizmu nie je čisto otázkou konfrontácie názorov, súdov či hodnôt aktérov, ale má aj praktický dopad na konanie aktérov. Materialita objektov tvorí súčast' týchto sporov, vstupuje do procesu argumentácie priamo ako dôkaz relevancie určitých podôb realizmu a moralizmu v konkrétnych situáciách konania. Čisto analyticky rozpojená materiálna realita objektov a symbolická realita významov sa z hl'adiska pragmatickej sociológie znovu prepojujú v interakčných situáciách. V týchto situáciách však hlavnú úlohu nezohrávajú individuálni aktéri vedení silami, ktoré by ich v týchto situáciách usmerňovali na základe ich vlastných záujmov, hodnôt a zdrojov. Ako sme mohli vidiet', v prípade Zbrojovky zohrali hlavnú úlohu momenty vynorujúcich sa príležitostí pretvárat' materialitu sveta $\mathrm{v}$ súlade $\mathrm{s}$ nasledovaním určitej vízie dobra.

\section{Literatura}

ANDRES, Lauren a Boris GRÉSILLON. Cultural brownfields in European cities: a new mainstream object for cultural and urban policies. International Journal of Cultural Policy, 2013, roč. 19, č. 1, s. 40-62. ISSN 1028-6632.

ASSMANN, Jan. Cultural memory and early civilization: writing, remembrance, and political imagination. Cambridge (UK): Cambridge University Press, 2011. ISBN 9780521188029.

BOLTANSKI, Luc. On critique: a sociology of emancipation. Cambridge (UK): Polity, 2011. ISBN 9780745649634.

BOLTANSKI, Luc a Laurent THÉVENOT. On justification: economies of worth. Princeton: Princeton University Press, 2006. ISBN 069111837x.

BOLTANSKI, Luc a Laurent THÉVENOT. The Sociology of Critical Capacity. European Journal of Social Theory, 1999, roč. 2, č. 3, s. 359-377. ISSN 1461-7137.

CRINSON, Mark. Urban memory: history and amnesia in the modern city. London: Routledge, 2005. ISBN 0415334055.

DROMI, Shai M. a Eva ILLOUZ. Recovering Morality: Pragmatic Sociology and Literary Studies. New Literary History, 2010, roč. 41, č. 2, s. 351-369. ISSN 1080-661X.

DURNOVÁ, Anna. A Tale of „Fat Cats“ and „Stupid Activists“: Contested Values, Governance and Reflexivity in the Brno Railway Station Controversy. Journal of Environmental Policy \& Planning, 2013, č. 4, s. 1-17. ISSN 1522-7200.

FAINSTEIN, Susan S. Economic Restructuring and Redevelopment. In KLENIEWSKI, Nancy (ed.). Cities and Society. Oxford: Blackwell Publishing, 2005, s. 167-182. ISBN 9781405102315.

FRANĚK, Otakar. Déjiny koncernu brněnské Zbrojovky. 1. díl. Brno: Blok, 1969.

FRANĚK, Otakar. Dějiny koncernu brněnské Zbrojovky. 3. díl. Brno: Blok, 1973.

GUIBERNAU, Monserrat. The Identity of Nations. Cambridge(UK): Polity, 2007. ISBN 9780745626628.

KLEIN, Kerwin Lee. On the Emergence of Memory in Historical Discourse. Representations, 2000, č. 69, s. 127-150. ISSN 1533-855X.

KLOCOKOVÁ, Jana a Andrej FINDOR. Politika sporu a (environmentálne) nové sociálne hnutia: hl'adanie vhodných analytických kategórií. Sociológia - Slovak Sociological Review, 2008, roč. 40, č. 2, s. 103-126. ISSN 0049-1225.

KLOCOKOVÁ, Jana. Možnosti a limity účasti verejnosti v environmentálnom rozhodovaní: Prípad Tatranského národného parku. In PLICHTOVÁ, Jana (ed.). Občianstvo, participácia a deliberácia na Slovensku: Teória a realita. Bratislava: Veda, 2010, s. 465-495. ISBN 978-80-224-1173-8. 
LNĚNIČKA, Libor. Post-industrial landscape of Bohemia-Moravian frontier region - New challenges, new opportunities. In SVOBODOVÁ, Hana (ed.). Geography and geoinformatics: Challenge for Practise and Education. Brno: Masarykova univerzita, 2012, s. 310-317. ISBN 978-80-2105799-9.

MARTIN, Ron L. a Bob ROWTHORN. The Geography of De-Industrialisation. London: Macmillan, 1986. ISBN 9780333371244.

NORA, Pierre. Between Memory and History: Les Lieux de Mémoire. Representations, 1989, č. 26, s. 7-24. ISSN 1533-855X.

SILBER, Ilana F. Pragmatic Sociology as Cultural Sociology: Beyond Repertoire Theory? European Journal of Social Theory, 2003, roč. 6, č. 4, s. 427-449. ISSN 1461-7137.

THÉVENOT, Laurent. Pragmatic Regimes Governing the Engagement with the World. In KNORRCETINA, Karin, Theodore R. SCHATZKI a Eike von SAVIGNI (eds.). The Practice Turn in Contemporary Theory. London: Routledge, 2001, s. 56-73. ISBN 9780415228138.

THÉVENOT, Laurent. The Plurality of Cognitive Formats and Engagements: Moving Between the Familiar and the Public. European Journal of Social Theory, 2007, roč. 10, č. 3, s. 409-423. ISSN 1461-7137.

THÉVENOT, Laurent. Convening the Company of Historians to Go into Conventions, Powers, Critiques and Engagements. Historical Social Research, 2012, roč. 37, č. 4, s. 22-35. ISSN 01726404.

WHITE, Hayden. Metahistory: The Historical Imagination in Nineteenth-Century Europe. Baltimore: Johns Hopkins University, 1975. ISBN 08018-17617.

ZABLOUDIL, Antonín a František ČAPKA. 100 let fotbalového klubu FC Zbrojovka Brno. Brno: CERM, 2013. ISBN 978-80-7204-834-2.

\section{Prameny}

BRNO-ŽIDENICE. O Židenicích. Oficiální stránky městské části [online]. C2013 [cit. 15.11.2013]. Dostupné z: http://www.zidenice.cz/mestska-cast/o-zidenicich/.

FC ZBROJOVKA BRNO. Historie brněnského fotbalového klubu. Oficiální web klubu [online]. C20112014 [cit. 15.11.2013]. Dostupné z: http://www.fczbrno.cz/zobraz.asp?t=klub-historie-historie-klubu.

JIŽNÍ CENTRUMBRNO. Současnostareálu Vaňkovka. Areál Vaňkovka[online]. C2012 [cit. 14.11.2013]. Dostupné z: http://www.arealvankovka.cz/index.php?option=com_content\&view=article\& $\mathrm{id}=106 \&$ itemid $=96 \&$ lang $=$ cs.

KURKA, Pavel. Lehký kulomet Bren. In: www.military.cz [online]. C2012 [cit. 19.11.2013]. Dostupné z: http://www.military.cz/czech/weapons/bren/bren.htm.

KRUTIL, Robin. Fotbalová Zbrojovka mění po roce majitele, koupil ji ,,muž z ústrani “ [online]. (C2013 [cit. 14.11.2013]. Dostupné z: http://brno.idnes.cz/brnenska-zbrojovka-opet-meni-majitele-dx6-/ brno-sport.aspx?c=A130507_1925895_brno-zpravy_taz.

MINISTERSTVO PRŮMYSLU A OBCHODU. Národni strategie regenerace brownfields [online]. Praha, C2008 [cit. 14.11.2013]. Dostupné z: http://www.czechinvest.org/data/files/strategie-regenerace-vlada-1079.pdf.

NEKOMPROMISNĚ. Skonči brněnská Wannieck Gallery? Petice se šiřri internetem i na papíre [online]. (C2013 [cit. 14.11.2013]. Dostupné z: http://www.nekompromisne.cz/skonci-brnenska-wannieck-gallery-petice-se-siri-internetem-i-na-papire.

OBČANSKÉ SDRUŽENÍ ŽIDENICE PRO OBČANY. Areál Zbrojovka Brno - odstranění staveb, vyjádřeni občanského sdruženi Židenice pro občany (OS ŽPO). 2008.

PELČÁK A PARTNER ARCHITEKTI. Nová Zbrojovka [online]. C2009 [cit. 15.11.2013]. Dostupné z: http://www.pelcak.cz/projekty/\#nova-zbrojovka-156. 
SLÉVÁRNA VAŇKOVKA. Vitejte na stránkách Slévárny Vaňkovka [online]. C2005 [cit. 19.11.2013]. Dostupné z: http://www.vankovka.cz/.

SLÉVÁRNA VAŇKOVKA. OS Vaňkovka [online]. (C2005 [cit. 19.11.2013]. Dostupné z: http://www. vankovka.cz/index.php?lang $=$ cz\&page $=5$.

THE INTERNATIONAL COMMITTEE FOR THE CONSERVATION OF THE INDUSTRIAL HERITAGE. The Nizhny Tagil Charter for the Industrial Heritage [online]. C2003 [cit. 14.11.2013]. Dostupné z: http://www.icomos.org/18thapril/2006/nizhny-tagil-charter-e.pdf.

ZBROJOVKA BRNO. Historie Zbrojovky Brno [online]. C2011-2014 [cit. 14.11.2013]. Dostupné z: http://www.zbrojovka-brno.cz/cz/pages/341-historie-zbrojovky-brno.aspx.

ZBROJOVKA BRNO. O společnosti [online]. [cit.14.11.2013]. Dostupné z: http://www.zbrojovka-brno. cz/en/pages/340-about-us.aspx.

\section{Autoři}

Ivana Rapošová je študentkou magisterského programu sociológie na Fakulte sociálních studií Masarykovej univerzity v Brne. Venuje sa sociálnej konštrukcii identít, kolektívnej pamäti a urbánnej sociológií.

Kontakt: 333300@mail.muni.cz

Apolónia Sejková je študentkou magisterského programu sociológie na Fakulte sociálních studií na Masarykovej univerzite v Brne. Zaoberá sa kultúrnou sociológiou.

Kontakt: 333187@mail.muni.cz

Csaba Szaló pôsobí na Katedre sociológie Fakulty sociálnych štúdií Masarykovej univerzity v Brne, kde sa zaoberá kultúrnou sociológiou. Jeho výskumné aktivity sa zameriavajú na proces kultúrnej asimilácie a sociálnej konštrukcie identít. Je riešitel’om medzinárodného výskumného projektu MEMOCITIES, ktorý sa venuje urbánnej pamäti.

Kontakt: szalo@mail.muni.cz 